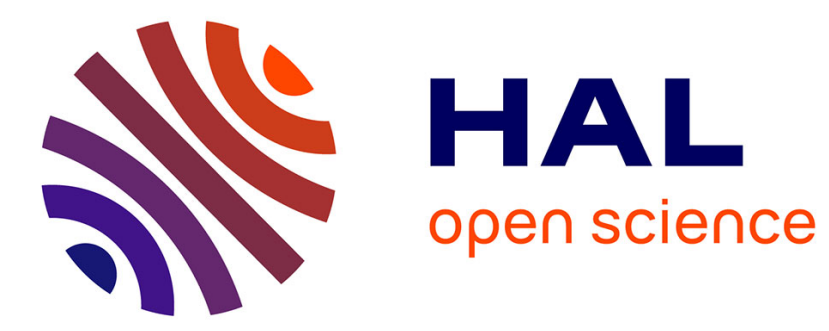

\title{
Nominal income versus Taylor-type rules in practice
} Jonathan Benchimol, André Fourçans

\section{To cite this version:}

Jonathan Benchimol, André Fourçans. Nominal income versus Taylor-type rules in practice. 2016. hal-01357870

\section{HAL Id: hal-01357870 \\ https://essec.hal.science/hal-01357870}

Preprint submitted on 31 Aug 2016

HAL is a multi-disciplinary open access archive for the deposit and dissemination of scientific research documents, whether they are published or not. The documents may come from teaching and research institutions in France or abroad, or from public or private research centers.
L'archive ouverte pluridisciplinaire HAL, est destinée au dépôt et à la diffusion de documents scientifiques de niveau recherche, publiés ou non, émanant des établissements d'enseignement et de recherche français ou étrangers, des laboratoires publics ou privés. 


\title{
a \\ ISSEC \\ BUSINESS SCHOOL
}

\section{NOMINAL INCOME VERSUS TAYLOR- TYPE RULES IN PRACTICE}

\author{
RESEARCH CENTER \\ JONATHAN BENCHIMOL, ANDRÉ FOURÇANS \\ ESSEC WORKING PAPER 1610
}

JULY 2016 


\title{
Nominal income versus Taylor-type rules in practice*
}

\author{
Jonathan Benchimol ${ }^{\dagger}$ and André Fourçans ${ }^{\ddagger}$ \\ July $4^{\text {th }}, 2016$
}

\begin{abstract}
Since the beginning of the financial crisis, a lively debate has emerged regarding which monetary policy rule the Fed (and other central banks) should follow, if any. To clarify this debate, several questions must be answered. Which monetary policy rule fits best the historical data? Which monetary policy rule best minimizes economic uncertainty and the Fed's loss function? Which rule is best in terms of household welfare? Among the different rules, are NGDP growth or level targeting rules a good option, and when? Do they perform better than Taylor-type rules? To answer these questions, we use Bayesian estimations to test the Smets and Wouters (2007) model under nine different monetary policy rules with US data from 1955 to 2015 and over three different sub-periods. We find that when considering only the central bank's loss function, the estimates generally indicate the superiority of NGDP level targeting rules, whatever the period. However, if other criteria are considered, the central bank's objectives are not consistently met by a single rule for all periods.

Keywords: Monetary policy, NGDP targeting, Taylor rule, DSGE model.

JEL Classification: E52, E58, E32.
\end{abstract}

${ }^{*}$ This paper does not necessarily reflect the views of the Bank of Israel. We thank Michael Belongia, Itamar Caspi, Weitzman Nagar, Akiva Offenbacher and participants of the Tel Aviv Macro Workshop for their useful comments.

${ }^{\dagger}$ Bank of Israel, Jerusalem, Israel. Corresponding author. Phone: +972-2-6552641. Fax: +972-2-6669407. Email: jonathan.benchimol@boi.org.il

${ }^{\ddagger}$ ESSEC Business School, Economics Department, Avenue Bernard Hirsch, 95021 Cergy Pontoise Cedex 2, France. Phone: +33-1-34433017. Fax: +33-1-34433689. Email: fourcans@essec.edu 


\section{Introduction}

Since the beginning of the Global Financial Crisis (GFC), there has been a lively debate among economists regarding which rules (if any) and objectives central banks should use to stabilize the economy. As interest rates declined to the Zero Lower Bound (ZLB), reductions in nominal interest rates may have dragged agents into liquidity traps and appeared to do little to stimulate economic activity. Consequently, nominal interest rates in various economies (the US, Eurozone and some other developed or emerging market economies) frequently deviated substantially from the path determined by standard or augmented Taylor rules.

Monetary economists generally contend that central bankers should follow policy rules rather than use their own discretion when devising monetary policy. Debates held during the 1970s and 1980s suggested nominal income targeting concepts, even if they were not always presented as such (Friedman, 1971; Meade, 1978; McCallum, 1973, 1987). The consensus on Taylor (1993) rules increased during the last two decades (Bernanke and Mishkin, 1997; Svensson, 1999; Taylor, 1999). However, criticism of such monetary policy rules also increased (Hall and Mankiw, 1994; Frankel and Chinn, 1995; McCallum and Nelson, 1999; Rudebusch, 2002a), especially during the GFC (Hendrickson, 2012; Woodford, 2012; Frankel, 2014; Sumner, 2014; Belongia and Ireland, 2015; McCallum, 2015; Sumner, 2015), arguing that nominal income targeting could be a better way to achieve the central banks' objectives.

Did paths deviating from a strict Taylor rule perform better in terms of achieving growth and stability than those generated by other Taylor-type rules? Would a nominal GDP (NGDP) rule be more effective for achieving price stability and high growth?

Addressing these questions is crucial to implement proper monetary policies.

An interesting way to compare and evaluate different monetary policy proposals and rules is to introduce them within the framework of a macroeconomic Dynamic Stochastic General Equilibrium (DSGE) model. Because the dynamics are so important and difficult to work through intuitively, these empirical models can provide invaluable assistance in clarifying the matter (Taylor, 2013).

As in Taylor and Wieland (2012), our objective is to use such models to evaluate different monetary policy rules and their consequences in terms of the central bank's loss and household welfare. Garín et al. (2016) perform such an analysis by evaluating the welfare properties of nominal GDP targeting. They find that output gap targeting is the most desirable rule but 
that nominal GDP targeting performs nearly as well.

Our paper compares Taylor-type and nominal income rules through the Smets and Wouters (2007) model, a well-known baseline DSGE model fitted for the US. In this model, both parameters and structural shocks are related to deeper structural parameters describing household preferences and technological and institutional constraints. These micro foundations provide a theoretical framework that could be particularly useful in an econometric analysis of the optimality of various policy strategies.

Our monetary policy rules are of three types: Taylor-type rules; nominal income growth targeting rules, and nominal income level targeting rules. There are three Taylor-type rules following: (1) a structure $\grave{a}$ la Smets and Wouters (2007), where the nominal interest rate responds to an inflation gap, an output gap and output-gap growth; (2) a structure à la Taylor (1993), where the nominal interest rate responds to an inflation gap and an output gap; and (3) a structure à la Galí (2015), where the nominal interest rate responds to an inflation gap, an output gap and a natural interest rate defined as the interest rate in the flexible-price economy. There are also three NGDP growth rules replacing the core functions of the Taylor-type rules with an NGDP growth targeting function. Finally, our last three rules replace the core functions of the Taylor-type rules with an NGDP level targeting rule.

As in An and Schorfheide (2007) and Smets and Wouters (2007), we apply Bayesian techniques to estimate our nine DSGE models (each type is composed of 3 structures) using US data. Note that such an approach is in the same vein as Garín et al. (2016). However, the model we use (Smets and Wouters, 2007) is more far reaching than theirs and widely accepted by monetary economists and central bankers. As noted below, our research object and methodology are also more comprehensive, as we study more policy rules than they do and do so over various time periods, in contrast to their estimates that run only from 1984 to 2007 (which is also one of our sample periods). Furthermore, we evaluate the rules not only through their impact on welfare, as those authors do, but also through different central bank loss functions, as well as other criteria. We believe that our analysis and estimates enrich theirs in an informative and interesting way.

Specifically, we estimate all of the parameters over several sample periods: the overall available sample (1955-2015) and three sub-samples with different economic environments and monetary policy styles, from 1955 to 1985, from 1985 to 2007, and from 2007 to 2015.

From the estimations and simulations of our models, differing only in the specifications of the monetary policy rules described above, we analyze, among other factors: parameters, in-sample and out-sample fits, the central bank's loss functions, households' welfare and their variances, impulse 
response functions, and variance decompositions.

We find that when considering only the central bank's loss function, the estimates generally indicate the superiority of NGDP level targeting rules, whatever the period. However, if other criteria are considered (fitting, households' welfare and its variance), the central bank's objectives are not met consistently by a single rule for all periods. To achieve the central bank's objectives, for each type of period (stable, crisis, recovery), a different central bank reaction function is more appropriate. Policy institutions, which base their forecasts and policy recommendations on such models and rules, should renew their estimates regularly. Another policy implication is that minimizing the Fed's selected variances does not automatically entail "good" first and/or second moments for household welfare.

The remainder of the paper is organized as follows. Section 2 describes the theoretical setup. Section 3 describes the empirical methodology. The results are presented in Section 4 and interpreted in Section 5. Section 6 concludes, and the Appendix presents additional empirical results.

\section{The models}

The Smets and Wouters (2007) model is the core model used in this paper. Yet, in this article and other working paper versions, those authors do not present the flexible-price economy. We do this work in the detailed description of the log-linearized sticky- and flexible-price economies in our Online Appendix.

This (generic) model, also detailed in the Online Appendix, needs to be completed by adding an ad hoc monetary policy reaction function (Table 1). Despite their different formulations, all of these functions include a smoothing process that captures the degree of rule-specific smoothing.

\section{Taylor-type rules}

- Model 1 is the original Smets and Wouters (2007) monetary policy rule, which gradually responds to deviations of inflation $\left(\pi_{t}\right)$ from an inflation objective (normalized to be zero), the output gap, defined as the difference between sticky-price $\left(y_{t}\right)$ and flexible-price $\left(y_{t}^{p}\right)$ outputs (see the Online Appendix), and deviations of the output gap from the previous period $\left(\triangle y_{t}-\triangle y_{t}^{p}\right)$.

- Model $\mathbf{2}$ is the Taylor (1993) monetary policy rule, which gradually responds to deviations of inflation from an inflation objective (normalized 
to be zero) and of the output gap, as previously defined. ${ }^{1}$

- Model 3 is the Galí (2015) monetary policy rule, which gradually responds to the natural interest rate $\left(r_{t}^{*}\right)$, as defined in Galí (2015), deviations of inflation from an inflation objective (normalized to be zero) and of the output gap, as previously defined.

\section{Nominal GDP growth rules}

- Model 4 is the Adapted NGDP Growth Targeting monetary policy rule, which gradually responds to deviations of nominal output growth $\left(\pi_{t}+\triangle y_{t}\right)$ from an objective ${ }^{2}$ and deviations of the output gap from the previous period (as in model 1).

- Model $\mathbf{5}$ is the NGDP Growth Targeting monetary policy rule, which gradually responds to deviations of nominal output growth from its flexible-price counterpart.

- Model 6 is the NGDP Growth Targeting monetary policy rule including a natural interest rate (NIR) component, where the policy gradually responds to the NIR and deviations of nominal output growth from its flexible-price counterpart.

\section{Nominal GDP level rules}

- Model 7 is the Adapted NGDP Level Targeting monetary policy rule, which gradually responds to nominal output level $\left(p_{t}+y_{t}\right)$ deviations from its flexible-price counterpart ${ }^{3}$ and deviations of the output gap from the previous period (as in model 1).

- Model $\mathbf{8}$ is the NGDP Level Targeting monetary policy rule, which gradually responds to nominal output level deviations from its flexibleprice counterpart.

- Model 9 is the NGDP Level Targeting monetary policy rule including a natural interest rate (NIR) component, where the policy gradually responds to the NIR and to deviations of the nominal output level from its flexible-price counterpart.

\footnotetext{
${ }^{1}$ In the original Taylor rule, the natural interest rate is constant (Taylor, 1993). Loglinearization around the steady-state eliminates this (constant) natural interest rate. Note that rule 1 (Smets and Wouters, 2007) does not either include the natural interest rate.

${ }^{2}$ Nominal output growth is $\pi_{t}+\triangle y_{t}$.

${ }^{3}$ The level of nominal output is $p_{t}+y_{t}$, where prices $p_{t}$ are deducted from the definition of inflation $\pi_{t}=p_{t}-p_{t-1}$.
} 


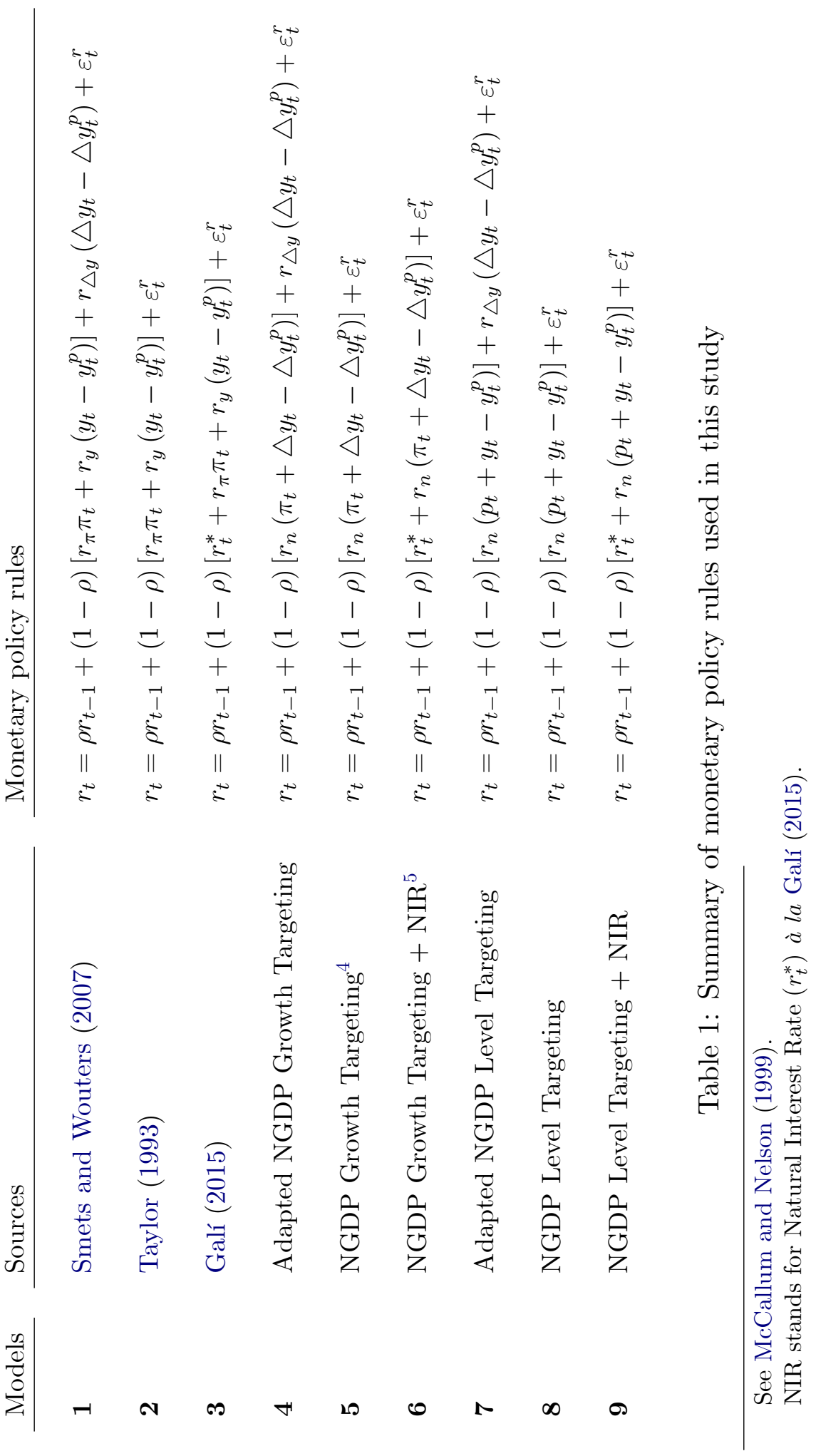


As indicated above, there are three categories of rules. The first three (1 to 3 ) are of the « Taylor-type ». Rules 4 to 6 are nominal GDP rules targeting nominal GDP growth. Rules 7 to 9 target the level of nominal GDP.

Rules 4 and 7 include an output gap growth, as in rule 1 (Smets and Wouters, 2003, 2007). Rules 6 and 9 include the natural interest rate, as in rule 3 (Galí, 2015). Including these variables allows us to compare the various rules with their standard versions as presented by the above-cited authors.

These three categories of rules represent the main policy rules in the contemporary literature.

As these rules are all ad hoc, they do not require changes in the specification of the core model. The unique deviating feature of the nine models therefore comes from their respective monetary policy rule. Concerning NGDP Level Targeting rules (models 7 to 9), we add to the core model and the monetary policy rule the definition of prices, derived from (in log form) $\pi_{t}=p_{t}-p_{t-1}$, where $p_{t}$ represents the log-price index at time $t$.

In addition, we assume that prices do not change over time in the flexibleprice economy, that is, (in $\log$ form) $p_{t}^{p}=p_{t-1}^{p}$ where $p_{t}^{p}$ represents the logprice index in the flexible-price economy at time $t$. Hence, $\pi_{t}^{p}=0$ and because our core model is computed in deviation from the steady state, $p_{t}^{p}=p_{t-1}^{p}=0$. Then, flexible-price nominal income is only defined by $\triangle y_{t}^{p}$ (growth) or $y_{t}^{p}$ (level). These assumptions are used in rules 4 to 6 (NGDP Growth rules in Table 1 ) and 7 to 9 (NGDP Level rules in Table 1 ).

\section{Methodology}

\subsection{Data}

The models, with various monetary policy rules, are estimated between 1955 and 2015 and over three different periods within this time interval: from 1955Q1 to 1985Q1, a period when the economy was rather unstable and featured ups and downs and when monetary policy could be characterized as discretionary; from 1985Q1 to 2007Q4, the Great Moderation era, when the economy was rather stable and monetary policy more predictable; and from 2007Q1 to 2015Q4, the GFC/ZLB era, the crisis and recovery period when monetary policy followed an unusual ZLB track.

During our first sub-sample (1955-1985), monetary policy was rather discretionary and severely criticized in the literature (Friedman, 1982). Since the 1980s, the predictability and stability of monetary policy has improved, 
with many researchers currently recommending rule-based rather than discretionary monetary policy decisions (Kydland and Prescott, 1977; Taylor, 1986, 1987; Friedman, 1982; Taylor, 1993). Notice that monetary policies occurring during our first sub-sample (1955-1985) were often modeled by a rule in the literature (Smets and Wouters, 2007; Nikolsko-Rzhevskyy and Papell, 2012; Nikolsko-Rzhevskyy et al., 2014).

Our second sub-sample (1985-2007) is inspired by Clarida (2010), describing the period 1985-2007 as the Great Moderation (GM). Although our second sub-sample is in line with the literature (Clarida, 2010; Meltzer, 2012; Taylor, 2012; Nikolsko-Rzhevskyy et al., 2014), we extend it until 2007, to define a sub-sample with a relatively stable economy (despite the Dot-com crisis beginning in the 2000s) that can be compared with the crisis period starting in 2007.

Our third sub-sample (2007-2015) is well documented in the crisis literature (Gorton, 2009; Cúrdia and Woodford, 2011; Benchimol and Fourçans, 2017).

Data for GDP (Real Gross Domestic Product, GDPC96), inflation (Implicit Price Deflator, GDPDEF), consumption (Personal Consumption Expenditures, PCEC), investment (Fixed Private Investment, FPI), and employment (Civilian Employment, CE16OV) are taken from the Bureau of Economic Analysis (U.S. Department of Commerce) database. Data for population (Civilian Noninstitutional Population, CNP16OV), worked hours (Average Weekly Hours from Nonfarm Business Sector, PRS85006023), and hourly wages (Compensation Per Hour from Nonfarm Business Sector, COMPNFB) are taken from the Bureau of Labor Statistics (U.S. Department of Labor) database. Data for the nominal interest rate (Effective Federal Funds Rate, FEDFUNDS) are taken from the Board of Governors of the Federal Reserve System database. The series are quarterly, and data transformations ${ }^{6}$ are exactly the same as in Smets and Wouters (2007).

\subsection{Calibration}

To maintain consistency across models for comparison purposes, we calibrate all core model parameters as in Smets and Wouters (2007). A detailed description of this calibration is provided in the Online Appendix.

Except for NGDP targeting rules, monetary policy rule parameters have the same calibration as in Smets and Wouters (2007) (Table 2).

Of course, $r_{\triangle y}$ equals zero in models $2,3,5,6,8$, and $9 . r_{\pi}$ and $r_{y}$ are

\footnotetext{
${ }^{6}$ For each period, we use the period-specific trend to detrend the data over the given period.
} 


\begin{tabular}{lllll} 
& Law & & Mean & Std. \\
\cline { 2 - 2 }$r_{\pi}$ & Beta & & 0.75 & 0.10 \\
$r_{y}$ & Normal & & 1.50 & 0.25 \\
$r_{\Delta y}$ & Normal & & 0.125 & 0.05 \\
$r_{n}$ & Normal & & 0.125 & 0.05 \\
\cline { 5 - 5 } & & & $1.5^{(*)} / 0.5^{(* *)}$ & 0.25
\end{tabular}

Table 2: Prior distribution of monetary policy rule parameters. $(*)$ stands for NGDP growth targeting (rules 4, 5 and 6$)$. (**) stands for NGDP level targeting (rules 7,8 and 9 ).

not used in models 4 to 9 , and $r_{n}$ is not used in models 1 to 3 .

As explained in Rudebusch (2002a), $r_{n}$ is higher than one for NGDP growth targeting rules, and positive and smaller than one for NGDP level targeting rules.

\subsection{Estimation}

As in An and Schorfheide (2007) and Smets and Wouters (2007), we apply Bayesian techniques to estimate our DSGE models with different specifications of monetary policy rules. We estimate all the parameters presented above over the four different periods defined in Section 3.1.

To avoid undue complexity, we do not present all the estimates. We prefer to concentrate on the analysis of the parameters of the different monetary rules. The other main estimation results are available in the Online Appendix, and detailed results are available upon request.

To achieve draw acceptance rates between $20 \%$ and $40 \%$, we calibrate the tuning parameter on the covariance matrix for each model and each period. Our results, for each model and each period, are based on the standard Monte Carlo Markov Chain (MCMC) algorithm with 2000000 draws of 5 parallel chains (where 1000000 draws are used for burn-in).

\section{Results}

Parameter estimates are detailed in the Online Appendix with all IRFs and variance decompositions. To draw policy conclusions from our models, we assess monetary policy rule parameters (estimated values) in Section 4.1, the models' in-sample fit in Section 4.2 (the models' out-sample fit is presented in the Online Appendix), central bank loss functions in Section 4.3, and 
household welfare in Section 4.4. We also discuss some impulse response functions in Appendix A and variance decompositions in Appendix B.

\subsection{Monetary rule parameters}

Fig. 1 presents the estimates of the smoothing parameter $(\rho)$, the inflation coefficient $\left(r_{\pi}\right)$, the output gap coefficient $\left(r_{y}\right)$, the output gap growth coefficient $\left(r_{\triangle y}\right)$ and the nominal income coefficient $\left(r_{n}\right)$.

As Fig. 1 shows, the smoothing parameter is in line with the literature (Justiniano and Preston, 2010), at approximately 0.8, and rather stable over time, although it appears somewhat smaller for rules 7 and 8, a result in line with Rudebusch (2002a,b).

The inflation coefficient (for rules 1 to 3 ) remains between 1.5 and less than 2, also in line with the literature (Smets and Wouters, 2007; Adolfson et al., 2011). Note that it is smaller during the GFC and recovery period (GFC/ZLB), suggesting less reaction by the Fed to inflation developments than during more stable periods, notably than during the GM, from 1985 to 2007.

Regarding the coefficient of the output gap, its value varies across the periods. It appears to be smaller during the GFC/ZLB period (it remains between 0.10 and 0.15 ) than between 1985 and 2007 (its value goes from 0.15 to 0.20 ). This difference is less significant when we compare the crisis period with the 1955-1985 period (except for rule 1).

These estimates of the Taylor-type rules (rules 1 to 3 ) imply a Fed that does not place greater emphasis (on the margin) on the output gap during the crisis than during the previous, stabler period.

Regarding the output gap growth coefficient, it varies somewhat across periods and rules (between 0.1 and 0.2). At least for rule 7, this coefficient appears to be somewhat higher during the GFC/ZLB than during the GM, implying a larger reaction to output growth during the crisis than during the previous, stabler period. For rule 1, this coefficient is highest during the sub-period 1955-1985, yet it remains the smallest, and significantly so, during the crisis sub-period.

The nominal income coefficient associated with the NGDP rules is higher for the growth rules than the level rules, over all periods, a result that is in line with the literature (Rudebusch, 2002a). For the growth and level rules, this coefficient is lower during the GFC/ZLB than otherwise, especially during the GM. The coefficient for the NGDP level rules changes (with time and rule), but is lower during the GFC/ZLB period than during the other periods. 

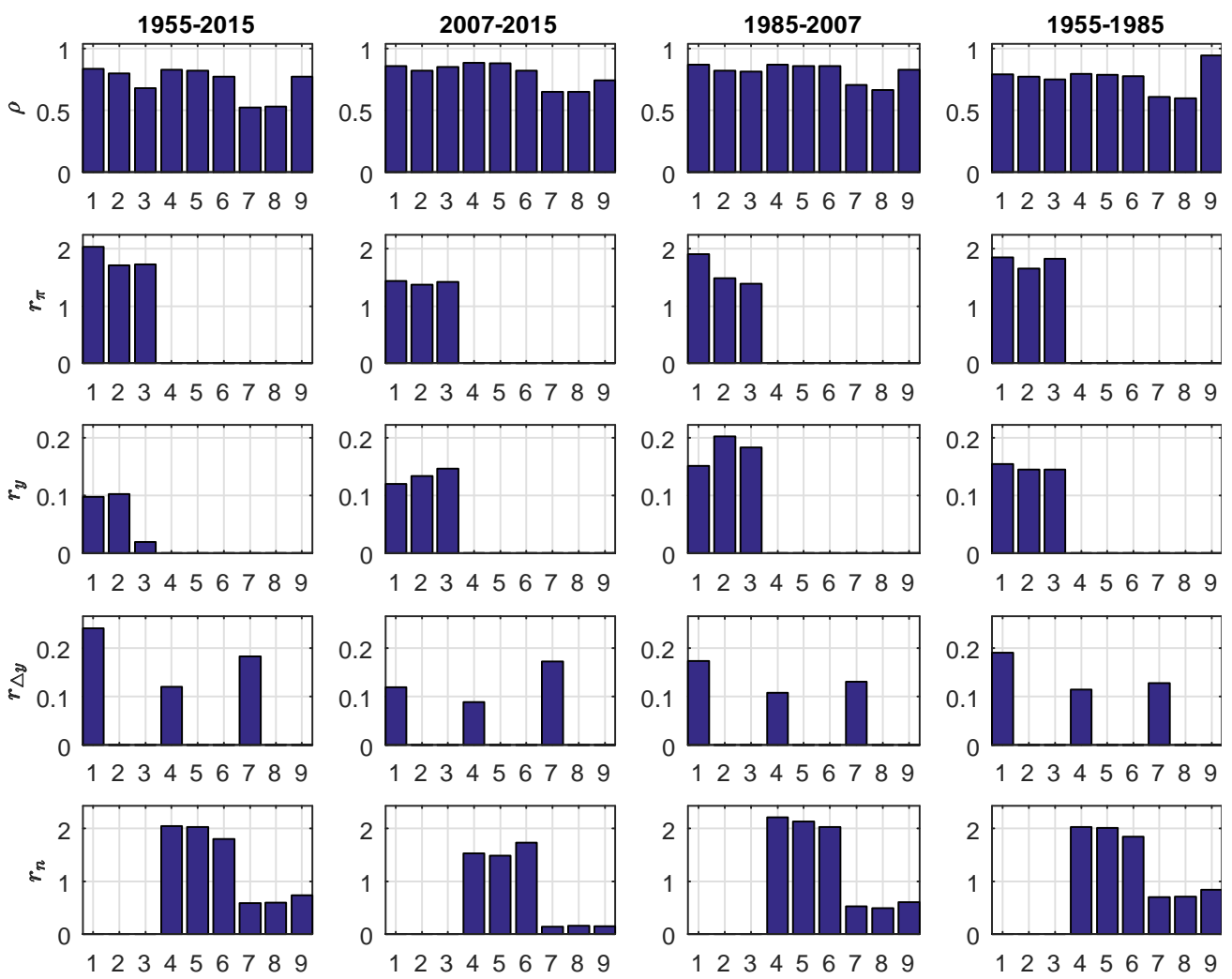

Figure 1: Monetary policy rule parameter values for each model (model 1 to model 9).

\subsection{In-sample fit}

Assessing in-sample fit is important to determine whether historical data (sample) are more or less in line with data generated by the estimated model. Table 3 shows the Laplace approximation around the posterior mode (based on a normal distribution), i.e., log marginal densities, for each model and for each sample.

Table 3 suggests that the first NGDP rule in levels (rule 7) best fits the historical data during the GFC/ZLB period. Another NGDP rule in levels (rule 8) exhibits the next-best fit. Rule 9, the last NGDP rule in levels, performs best during the GM period, while the Smets and Wouters (2007) rule ranks just after. Furthermore, rule 1 dominates the other rules over the period 1955-1985 and over the full sample.

For each period, a different monetary policy rule best fits the historical data. Note that standard Taylor-type rules (rules 2 and 3) and NGDP growth targeting rules (rules 4,5 , and 6 ) are generally inferior to the other rules in 


\begin{tabular}{|c|c|c|c|c|c|c|c|c|c|}
\hline & \multicolumn{9}{|c|}{ Rules } \\
\hline & 1 & 2 & 3 & 4 & 5 & 6 & 7 & 8 & 9 \\
\hline $1955-2015$ & -1443 & -1511 & -1514 & -1455 & -1478 & -1467 & -1513 & -1573 & -1539 \\
\hline $2007-2015$ & -276 & -245 & -264 & -288 & -279 & -286 & -230 & -239 & -265 \\
\hline $1985-2007$ & -405 & -435 & -425 & -415 & -414 & -410 & -411 & -428 & -401 \\
\hline $1955-1985$ & -819 & -838 & -837 & -849 & -847 & -835 & -847 & -854 & -854 \\
\hline
\end{tabular}

Table 3: Log marginal data densities for each model and each period (Laplace approximation).

explaining historical data.

Nevertheless, note that this result does not imply that models with lower log marginal data densities should be discarded. Whatever the log marginal data density function, it may be argued that each model is designed to capture only certain characteristics of the data. Whether the marginal likelihood is a good measure to evaluate how well the model accounts for particular aspects of the data is an open question (Koop, 2003; Fernández-Villaverde and Rubio-Ramírez, 2004; Del Negro et al., 2007; Benchimol and Fourçans, 2017).

To further judge the fit of the different models, we calculated the Root Mean Square Deviations (RMSD) between model-based and historical values of some variables. Fig. 2 presents in-sample errors, measured as the sum of normalized RMSD between model-based and historical variables with respect to the nominal interest rate, inflation and output growth for each period. Normalized RMSD, defined as the ratio between standard RMSD and the difference between the maximum and the minimum value of the historical variable (in the relevant sample), facilitates comparison across datasets and models with different scales. ${ }^{7}$

Regarding the interest rate, rule 6 dominates the others in each period except the GM period, when rule 2 performs best (with 5 and 8 not far in terms of RMSD values).

When inflation and output growth are considered, the RMSDs are higher during the 2007-2015 period than during the other periods, an unsurprising result given the instability associated with the GFC/ZLB period. During this period, rule 6 dominates the others, except for output growth, for which rules 1 and 3 perform better.

During the GM period, the results are somewhat mixed, but the Taylor

\footnotetext{
${ }^{7}$ Although there is no consistent means of normalization in the literature, the range of the measured data, defined as the maximum value minus the minimum value, is a common choice. Moreover, this choice is relevant for our case as long as we examine datasets that include negative values.
} 

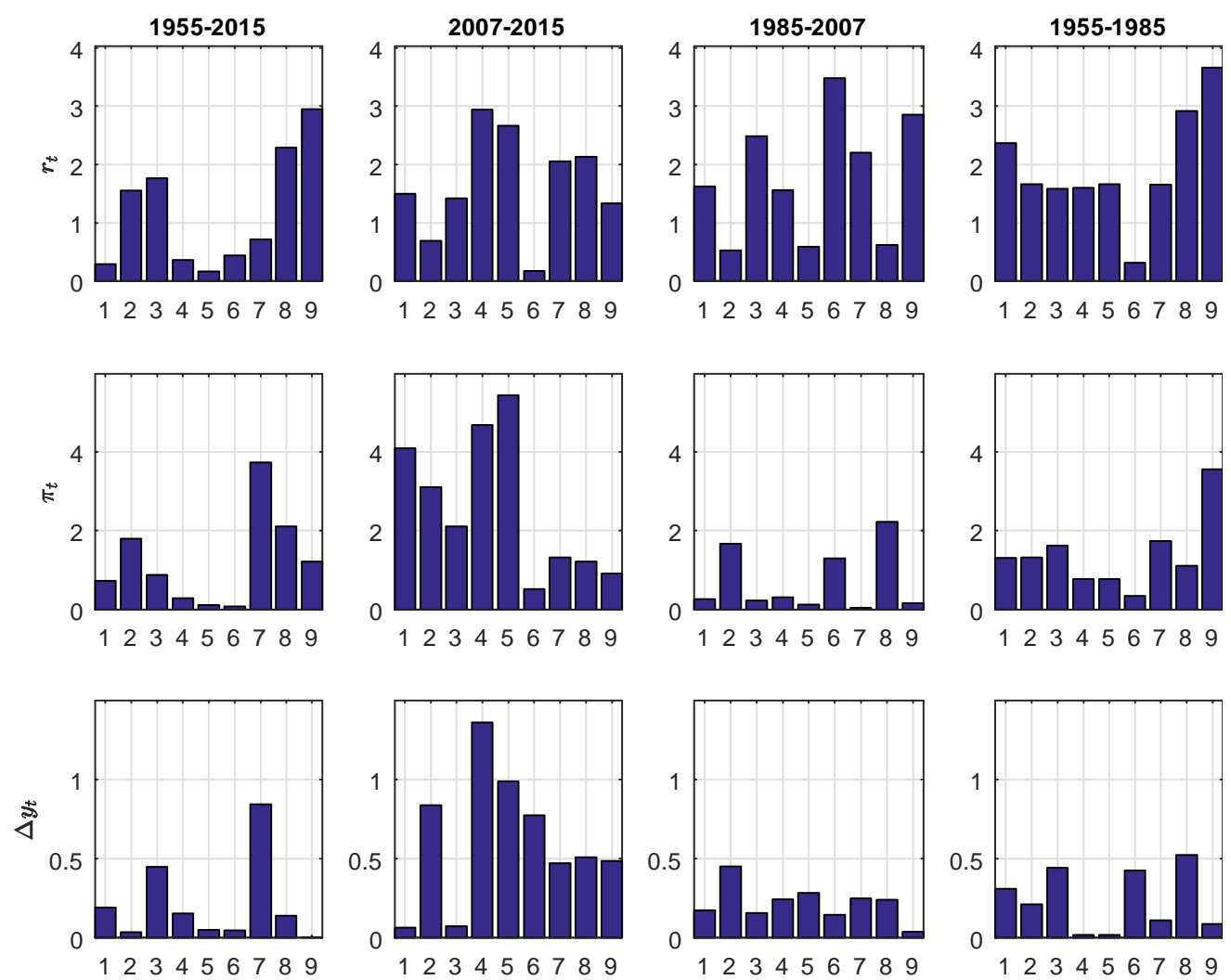

Figure 2: Normalized RMSD between model-based and historical nominal interest rate, inflation, and output differential, for each period (in \%).

rule (rule 2) performs poorly compared with the other rules when the RMSD values for inflation and output growth are considered.

These results show that, again, no single rule performs best over the different periods and for all variables.

\subsection{Central bank losses}

In this section, we present several loss measures based on the variance of the variables of interest from the central bank's perspective. These variances are estimated for each model and for each period.

Many ad hoc central bank loss functions appear in the literature (Svensson and Williams, 2009; Taylor and Wieland, 2012; Adolfson et al., 2014). Our methodology intends to summarize all standard possibilities. For various sets of weights defining these functions, we compute the ex post optimal rule, consistent with the estimated DSGE model. This approach is used extensively in the literature to investigate monetary policy rules (Taylor, 
1979; Fair and Howrey, 1996; Taylor, 1999).

Non-separability between consumption and labor (worked hours) in Smets and Wouters (2007) household's utility function (see Section 4.4) introduces labor-related variables into the inflation and output equations. By minimizing its loss function with respect to these two equations, the central bank must also consider labor-related variables, such as wages (price of worked hours).

Our general central bank loss function, $L_{t}$, is defined in line with Galí (2015), as

$$
L_{t}=\operatorname{var}\left(\pi_{t}\right)+\lambda_{y} \operatorname{var}\left(y_{t}-y_{t}^{p}\right)+\lambda_{\Delta r} \operatorname{var}\left(\Delta r_{t}\right)+\lambda_{w} \operatorname{var}\left(w_{t}\right)
$$

where $\lambda_{y}$ is the weight on output gap variances, $\lambda_{\Delta r}$ the weight on nominal interest rate differential variance, and $\lambda_{w}$ the weight on wage inflation variance. The weight on price inflation variance is normalized to unity, and $\operatorname{var}($.$) is the variance operator. \pi_{t}$ is price inflation, $y_{t}-y_{t}^{p}$ the output gap, $\Delta r_{t}$ nominal interest rate differential, and $w_{t}$ wage inflation ${ }^{8}$ (see the Online Appendix for more details about the variables).

In this section, we only present central bank losses with $\lambda_{w}=0$. The Online Appendix presents central bank losses with $\lambda_{w}=0.5$ and $\lambda_{w}=1$.

First, in Fig. 3, we present the estimated variances of each variable (inflation, output gap, nominal interest rate differential, and wage inflation) entering the central bank loss functions.

The variances of all variables under consideration are significantly higher before 1985 and over the full sample. Even during the 2007-2015 period, these variances were lower than before 1985 and little different than during the GM period. The fact that estimated variances over the GFC/ZLB period are comparable across the models with those of the GM period does not mean that variances of historical data during the GFC/ZLB and GM are comparable. Indeed, the variances presented in Fig. 3 are estimated from the models while assuming that the Fed followed various rules and the US economy behaved as in the Smets and Wouters (2007) model. The high inflation period cum various significant ups and downs in economic activity and interest rates explain the high values observed between 1955 and 1985 .

However, changes in the Fed's monetary policy and the stabilization period that occurred during the 1990s explain the low variance of the GM

\footnotetext{
${ }^{8}$ Another loss measure based on the squared distance of variables generated by the models can be defined:

$$
L_{t}=\pi_{t}^{2}+\lambda_{y} y_{t}^{2}+\lambda_{r}\left(\Delta r_{t}\right)^{2}+\lambda_{w} w_{t}^{2}
$$

Empirically, this type of formulation leads to similar results to those given by Eq. 1.
} 

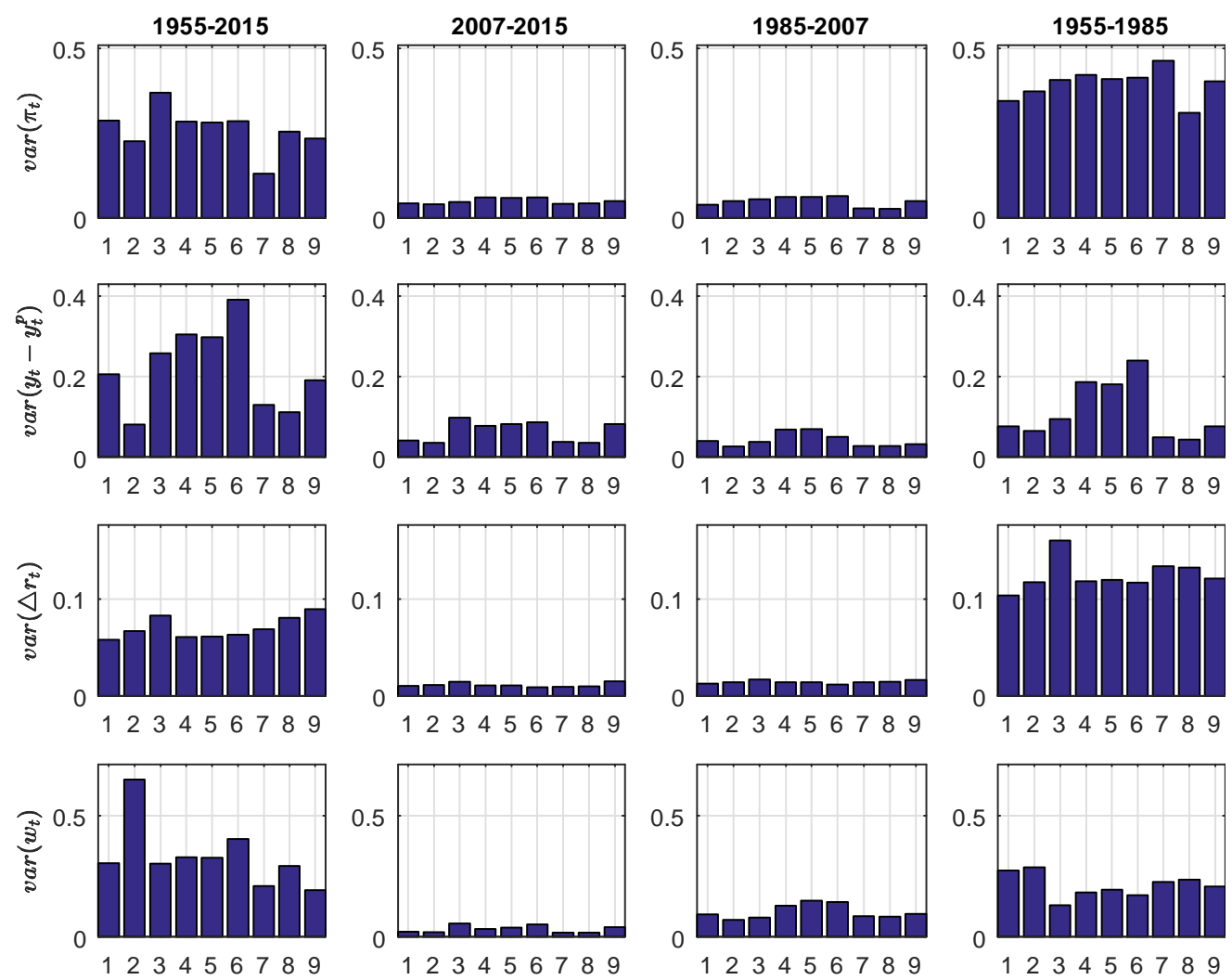

Figure 3: Estimated variances of central bank loss function variables, for each period and each rule.

period relative to the $1955-1985$ period. Output variances are somewhat higher during the GFC/ZLB period than during the GM period, while those of the inflation rate are close. The low interest rates of the GFC/ZLB period lead to lower variances of the interest rate differentials during the GFC/ZLB than during the GM period. The variances of wages were also smaller during the GFC/ZLB period than during the GM period.

Second, we compute ad hoc loss functions based on Eq. 1 (with $\lambda_{w}=0$, as was said earlier). Figs. 4 to 7 present central bank losses with respect to various loss functions, over our time periods and for each monetary policy rule.

For a given weight on the variance of the interest rate differential $\left(\lambda_{\Delta r}\right)$, the loss diminishes for all rules and for all periods when the weight on the variance of the output gap diminishes (vertical observation). For a given weight on the variance of the output gap $\left(\lambda_{y}\right)$, the loss diminishes, albeit to a limited extent, for all rules and for all periods when the weight on the 

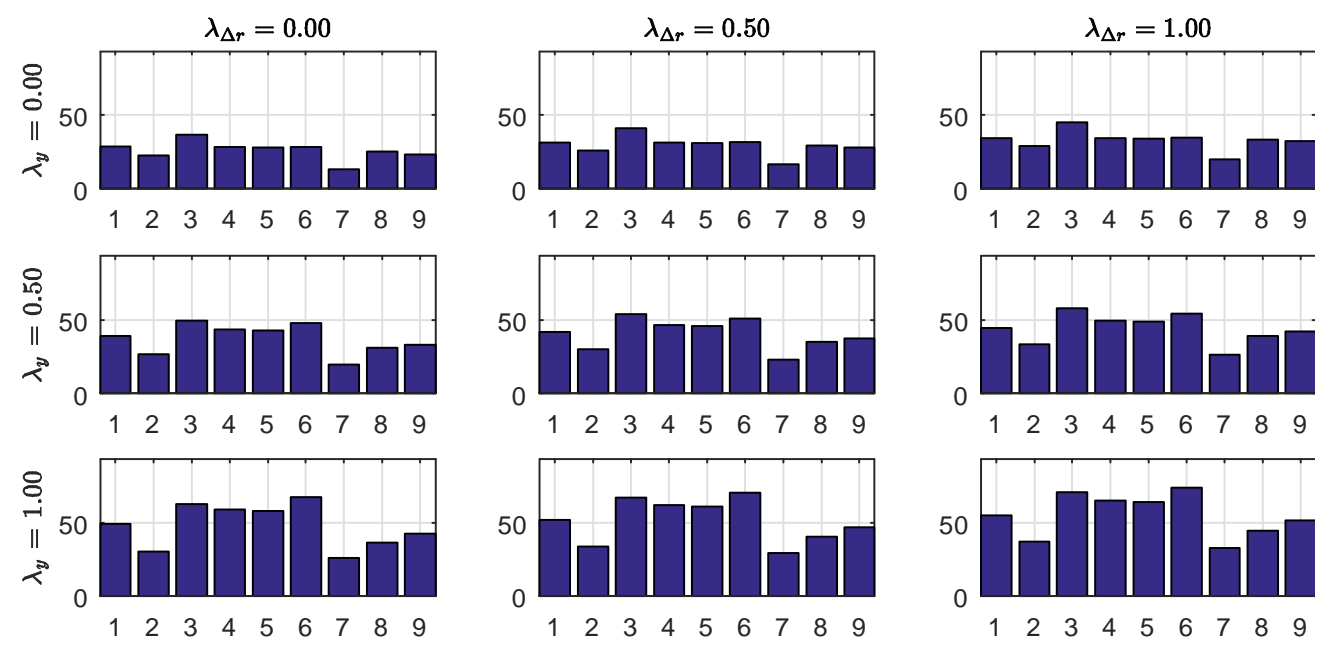

Figure 4: Central bank losses, for each rule, between 1955 and 2015
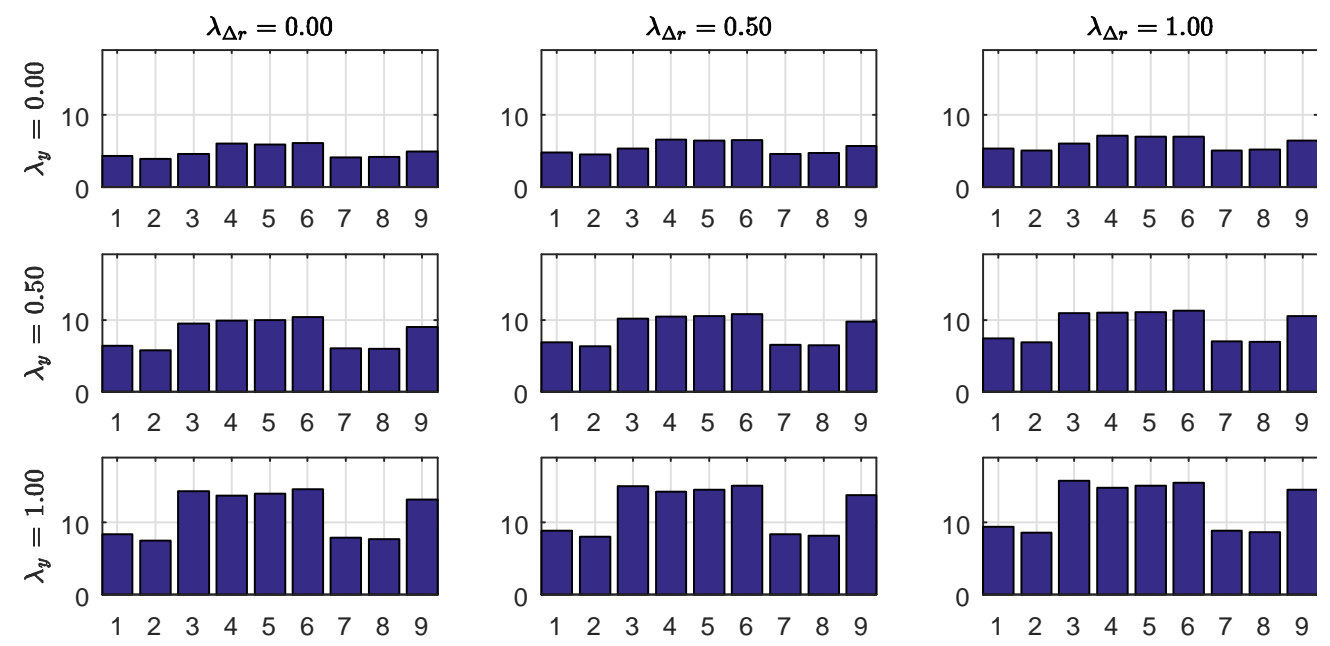

Figure 5: Central bank losses, for each rule, between 2007 and 2015 

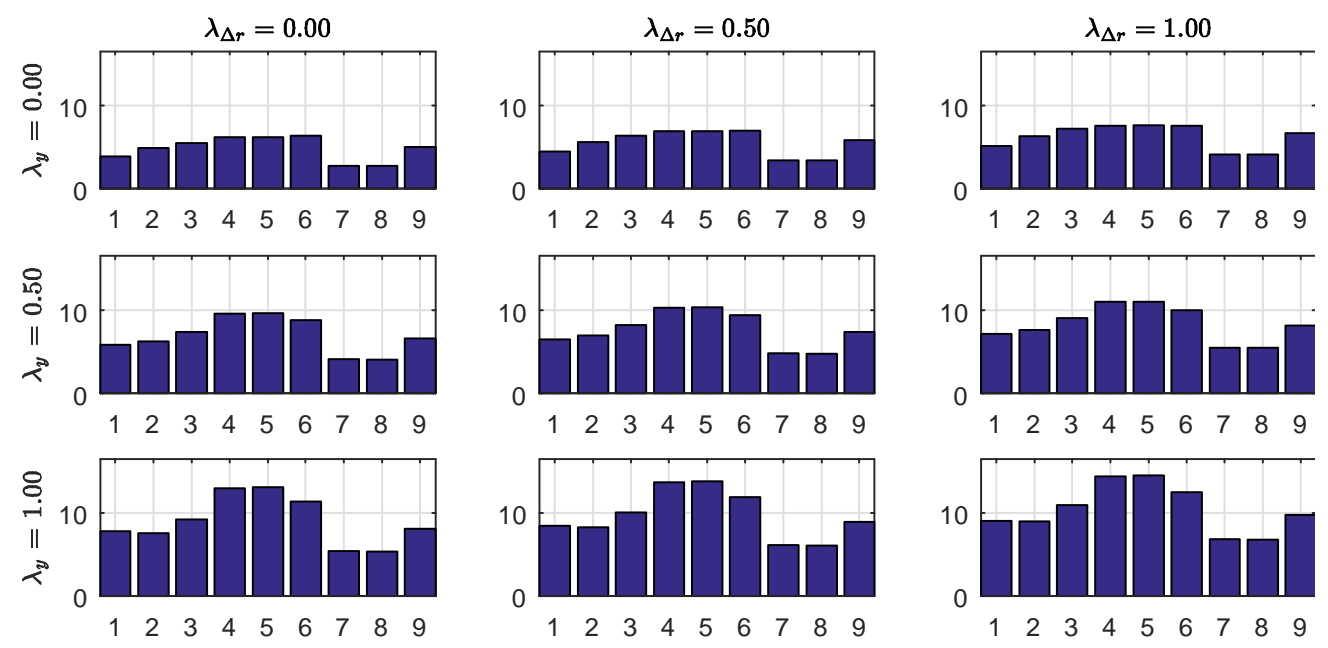

Figure 6: Central bank losses, for each rule, between 1985 and 2007
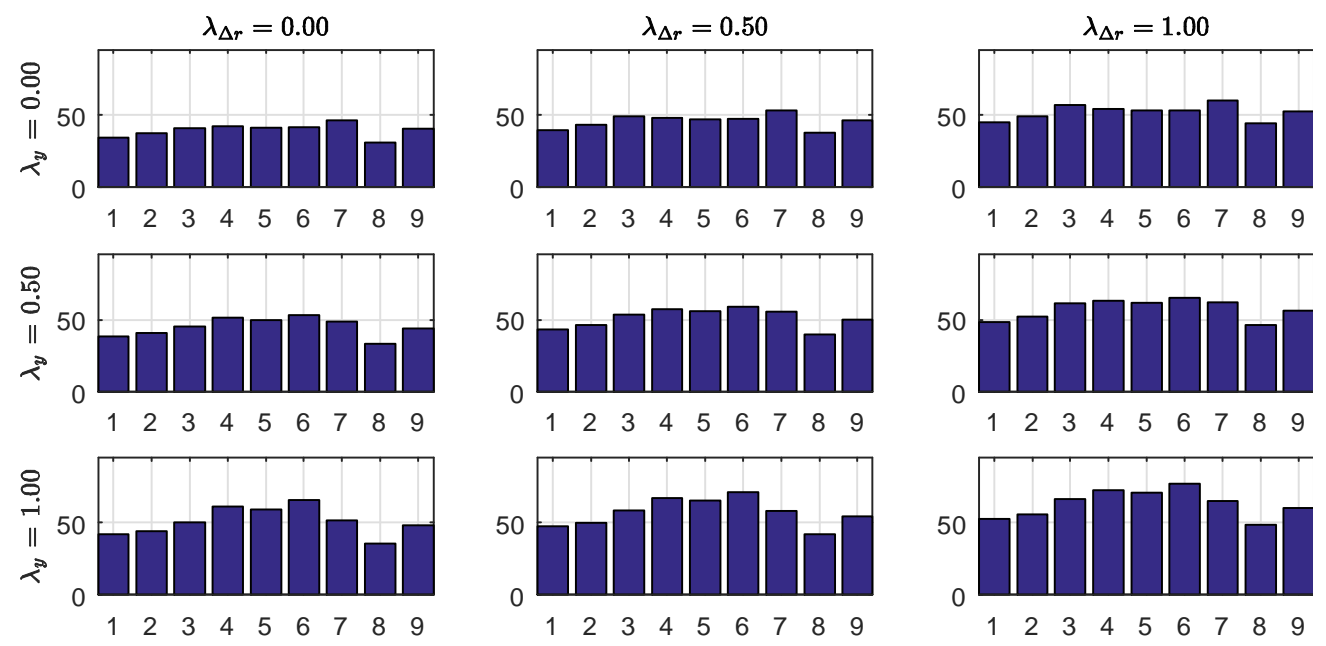

Figure 7: Central bank losses, for each rule, between 1955 and 1985 
variance of the interest rate differential diminishes (horizontal observation). These results are directly related to the simple (linear) functional form of the central bank loss function.

Interestingly, the change in the loss is very minor for a given $\lambda_{y}$ (horizontal observation) compared to the change in the loss for a given $\lambda_{\Delta r}$ (vertical observation). This result would imply that a central bank gains almost nothing by including the interest rate differential in its loss function.

One can interpret this result in light of the interest rate smoothing assumption. Most of the monetary policy rules used in the literature assume interest rate smoothing, as we do. This smoothing implies that the central bank already minimizes the variances in the interest rate differential over time, hence the small gain generated by changing the interest rate differential coefficient in the central bank loss function for a given $\lambda_{y}$ (horizontal observation).

Note also that whatever the values of $\lambda_{y}$ and $\lambda_{\Delta r}$ during the GFC/ZLB, rules 7 and 8 dominate the others, but rules 1 and 2 lead to nearly similar values.

For the GM period (1985-2007), the NGDP rules in levels, rules 7 and 8, dominate even more clearly the other policy reaction functions.

During the 1955-1985 period, NGDP level targeting rule 8 leads to the lowest loss, but here too, rule 1 performs well.

From the full sample estimates, it appears that NGDP level targeting rule 7 is the best to minimize losses.

From these observations, we infer that during the exceptional GFC/ZLB period, the Fed would have minimized its loss by following an NGDP rule in levels, especially rules 7 and 8 . However, had it employed Taylor-type rules 1 and 2 , the difference in terms of loss would have been minor.

\subsection{Households' welfare}

Households' utility-based welfare is measured as the sum over a sampleperiod of each quarter's utility value. The utility function, from Smets and Wouters (2007), is given by

$$
U_{t}=\frac{1}{1-\sigma_{c}}\left(C_{t}-h C_{t-1}\right)^{1-\sigma_{c}} \exp \left(\frac{\sigma_{c}-1}{1+\sigma_{l}} L_{t}^{1+\sigma_{l}}\right)
$$

where $C_{t}$ is households' consumption and $L_{t}$ worked hours. $h$ represents the households' consumption habits, $\sigma_{c}$ households' relative risk aversion, and $\sigma_{l}$ the Frish elasticity (for further details, see the Online Appendix). exp (.) is the exponential operator. 


\begin{tabular}{rrrrrrrrrr} 
& \multicolumn{10}{c}{ Rules } \\
\cline { 2 - 10 } $1955-2015$ & 2768 & $\mathbf{6 5 3 4}$ & 2118 & 4604 & 3868 & 4475 & 2609 & 3032 & 3558 \\
$2007-2015$ & 6 & -11 & 28 & -9 & 14 & 22 & 6 & -4 & $\mathbf{3 5}$ \\
$1985-2007$ & 226 & $\mathbf{6 2 1}$ & 111 & 195 & 168 & 140 & 273 & 144 & 137 \\
$1955-1985$ & 816 & 678 & 360 & 999 & $\mathbf{1 0 0 0}$ & 873 & 584 & 234 & 287
\end{tabular}

Table 4: Households' welfare measured as the sum of the first-period utility $\left(u_{t}\right)$ function over time.

Table 4 presents household welfare estimates for each rule and each period. During the GFC/ZLB, rule 9 (targeting the level of NGDP cum the natural interest rate) leads to the highest welfare. However, during the GM period, rule 2 (Taylor rule) that dominates (as is the case over the whole sample period). From 1955 to 1985, rules 4 and 5 appear to result in the highest welfare. The other NGDP growth targeting rule 6 also performs better than Taylor-type rules.

One can tentatively infer from these observations that during stable periods, the traditional Taylor rule maximizes households' welfare, whereas during crises and less-stable periods, some NGDP targeting-type rules are more appropriate.

In addition to the impact on the level of households' welfare, it is also interesting to study the impact on the variance of this welfare. Table 5 presents these estimates.

\begin{tabular}{ccrrrrrrrr} 
& \multicolumn{10}{c}{ Rules } \\
\cline { 2 - 10 } & 1 & 2 & 3 & 4 & 5 & 6 & 7 & 8 & 9 \\
$1955-2015$ & 1,44 & 14,09 & $\mathbf{0 , 5 7}$ & 1,17 & 1,14 & 1,35 & 1,89 & 1,88 & 0,72 \\
$2007-2015$ & 0,04 & 0,07 & 0,05 & $\mathbf{0 , 0 2}$ & 0,03 & $\mathbf{0 , 0 2}$ & 0,04 & 0,05 & 0,03 \\
$1985-2007$ & 0,09 & 0,50 & 0,06 & 0,07 & 0,07 & $\mathbf{0 , 0 4}$ & 0,17 & 0,17 & 0,07 \\
$1955-1985$ & 2,21 & 2,59 & $\mathbf{0 , 4 7}$ & 0,91 & 0,94 & 0,80 & 2,37 & 2,41 & 1,77
\end{tabular}

Table 5: Households' welfare variance for each period and each model.

During the GFC/ZLB period, the NGDP targeting rules 4 and 6 (targeting NGDP growth with the natural interest rate included) perform better than the other rules, but the other NGDP growth targeting rule (5) and rule 9 lead to nearly similar results. During the GM period, rule 6 is the best. For the 1955-1985 period, rule 3 dominates, with rule 6 performing nearly as well. 
Note that, over all periods, the standard Taylor rule (2) leads to the highest variance, i.e., leads to the worst performance in terms of welfare variance.

From these observations, NGDP growth targeting cum the natural interest rate (rule 6) appears to be a "good" rule whatever the economic situation of the period, and it is the best rule over the GFC/ZLB and GM periods.

\section{Interpretation}

Table 6 summarizes our results to capture essential facts of our exercise.

\begin{tabular}{|c|c|c|c|c|}
\hline \multirow[b]{2}{*}{ Fitting } & $1955-2015$ & $2007-2015$ & $1985-2007$ & $1955-1985$ \\
\hline & & & & \\
\hline Marginal density & 1 & 7 & 9 & 1 \\
\hline $\operatorname{RMSD}\left(r_{t}\right)$ & 5 & 6 & $2,5,8$ & 6 \\
\hline $\operatorname{RMSD}\left(\pi_{t}\right)$ & 5,6 & 6 & $5,7,9$ & 6 \\
\hline $\operatorname{RMSD}\left(\triangle y_{t}\right)$ & 9 & 1,3 & 9 & 4,5 \\
\hline
\end{tabular}

\section{Central bank losses}

\begin{tabular}{lcccc}
\cline { 1 - 3 } $\operatorname{var}\left(\pi_{t}\right)$ & 7 & 7,8 & 7,8 & 8 \\
$\operatorname{var}\left(y_{t}-y_{t}^{p}\right)$ & 2 & 7,8 & $7,8,9$ & 7,8 \\
$\operatorname{var}\left(\Delta r_{t}\right)$ & $1,4,5$ & $\mathrm{NR}$ & $\mathrm{NR}$ & 1 \\
$\operatorname{var}\left(w_{t}\right)$ & 9 & $2,7,8$ & $2,3,7,8$ & 3 \\
Loss functions* & 7 & $2,7,8$ & 7,8 & 8 \\
Loss functions** & 7 & 7,8 & 7,8 & 8 \\
& & & & \\
Households & & 9 & 2 & 4,5 \\
Welfare mean & 2 & 4,6 & 6 & 3 \\
Welfare variance & 3 & & &
\end{tabular}

NR stands for non-relevant, i.e., impossible to discriminate.

*Including $\operatorname{var}\left(\pi_{t}\right), \operatorname{var}\left(y_{t}-y_{t}^{p}\right)$, and $\operatorname{var}\left(\Delta r_{t}\right)$ only (Section 4.3)

**Including $\operatorname{var}\left(\pi_{t}\right), \operatorname{var}\left(y_{t}-y_{t}^{p}\right), \operatorname{var}\left(\Delta r_{t}\right)$, and $\operatorname{var}\left(w_{t}\right)$ (Online Appendix)

Table 6: Summary of the best rule(s) for each criterion

In terms of fitting the data, the marginal density values show that rule 1 performs better than all others for the full sample and the 1955-1985 period.

Rule 7 is best in terms of log marginal data densities during the GFC/ZLB. During the GM period, rule 9 leads to the highest marginal density, i.e., the best fit. 
Yet, for reasons explained in Section 4.2, the values of the marginal densities are not definitive proof that we have the correct ranking of rules. These values constitute an indication of which rules were more or less followed during the different periods, assuming that the Fed followed a policy rule and assuming that the economy behaved as in the Smets and Wouters (2007) model.

From the RMSD of interest rates and inflation, NGDP targeting rule 6 performs better during the GFC/ZLB and 1955-1985 periods, whereas rule 5 dominates during the GM period (with rules 7, 8 and 9 being close).

Regarding the RMSD of output growth, the Taylor rule à la Smets and Wouters (2007) and à la Galí (2015) perform best during the crisis. NGDP targeting rules dominate over the other periods (rule 9 for the GM period and rules 4 and 5 from 1955 to 1985).

In terms of out-of-sample forecasts, the results are somewhat different, as NGDP growth targeting rule 5 is better during the GFC/ZLB and the other results are less clear (Online Appendix).

The results are clearer when we analyze the losses of the central bank. They all lead to the general superiority of NGDP level targeting rules for all periods with few exceptions. The results are somewhat different when we analyze the variances of the specific variables entering the loss functions.

Regarding households' welfare level, NGDP targeting leads to better results during the GFC/ZLB period (rule 9) and from 1955 to 1985 (rules 4 and 5), whereas the standard Taylor rule (rule 2) dominates during the GM and the full sample periods. In terms of welfare variance, the results vary with the sub-periods with a preference for NGDP growth targeting rules for the GFC/ZLB and GM periods.

These results are not intended to prove that the Fed followed a given type of rule depending on the period. An explicit rule is only a model that attempts to capture some monetary policy parameters explaining how the central bank determines its interest rate.

According to Table 6, the Fed's decisions were generally more in line with NGDP targeting rules during the GFC and GM than with other rules, to the extent that the US economy behaved à la Smets and Wouters (2007). Our estimates also show that the Fed's monetary policy, modeled by Taylor rules and NGDP growth rules, would not have minimized the central bank's loss functions over these periods (GFC/ZLB and GM); NGDP targeting in levels performs better. The implication is somewhat different when considering the impact of each rule on the mean and variance of welfare. 


\section{Conclusion}

The purpose of this paper is to shed light on the effects of different monetary policy rules on the macroeconomic equilibrium. Specifically, we seek to determine, first, which monetary policy rule is most in line with the historical data for the US economy and, second, what policy rule would be best to minimize the central bank's loss function and/or maximize households' welfare - and/or minimize its variability. The first consideration is "positive", the second is "normative".

To conduct this type of analysis, we compare Taylor-type and nominal income rules through the well-known Smets and Wouters (2007) DSGE model.

We consider nine monetary policy rules. Three are of the "Taylor-type" and six are of the nominal income targeting type (NGDP), either in growth or levels. We test the model with these various rules through Bayesian estimations from 1955 to 2015, over three different periods: 1955-1985, 1985-2007, and 2007-2015. These sub-periods are selected to capture the impact of policy rules given different economic environments (more or less stable periods and crisis and recovery periods).

In terms of fit with historical data, the marginal density values suggest that some NGDP targeting rules exhibit the best fit during the GFC/ZLB and GM periods. The Taylor-type rule à la Smets and Wouters (2007) performs best over the 1955-1985 period (and over the full sample). However, other measures of this fit (RMSD estimates) do not always support this conclusion. Depending on the variable under consideration (interest rate, inflation or output), NGDP targeting rules often dominate the Taylor-type rules). Several NGDP-type rules often exhibit better forecasting performance than do Taylor-type rules, at least during the GFC/ZLB period. Out-sample fit tests show that the choice of a monetary policy rule does not significantly impact the forecasting performance of the model.

The results regarding the losses of the central bank are clearer. All estimates suggest, in general, the superiority of NGDP level targeting rules, whatever the sub-period.

Regarding households' welfare, one NGDP rule maximizes its level during the GFC/ZLB period. During the GM, the Taylor rule performs best. In minimizing welfare variance, some NGDP rules dominate the other rules.

A first policy implication is that central bank's objectives are not achieved by a single rule, irrespective of the period in question. For each period, there is a preferred monetary policy reaction function. In other words, for each type of period (more or less stable, crisis, recovery), one central bank reaction function performs better than others. Yet, if we only consider the loss function of the central bank, the results lead to the general superiority of NGDP 
rules in levels (even if the Taylor rule leads to nearly similar implications over the GFC/GM periods).

A second implication is that for a given monetary policy rule, parameter estimates change with respect to the period considered. Policy institutions, which base their forecasts and policy recommendations on such models and rules, should renew their estimates regularly to avoid inaccurate policy conclusions.

A third policy implication directly concerns central bank objectives. It is standard to assume that a central bank seeks to minimize a loss function that includes, at least, inflation and output variances. Would this minimization process automatically lead to a maximization of households' welfare (and/or a minimization of households' welfare variance)? Our results show that this is not necessarily the case.

\section{Appendix}

\section{A Impulse response functions}

Figs. 8 to 11 present impulse responses of the main variables of interest (inflation, output and welfare) with respect to three shocks (monetary policy, technology and government expenditure). The IRFs for all variables and all shocks, as well as a special presentation of on-impact responses, are shown in the Online Appendix.

The impact of a monetary policy shock on inflation is strongest under rule 6 during the GFC/ZLB period and during the GM period. Rule 3 leads to the highest impact before 1985 and over the whole sample, but rule 6 performs almost as well. Regarding the short-run impact on output, rule 3 dominates the others during the GFC/ZLB and the GM periods, but rules 6 and 9 do not produce markedly different results. Rule 6 leads to the highest impact over the period 1955-1985 and rule 9 over the full sample. When considering the on-impact on welfare, rule 3 again yields the highest value from 2007 to 2015, but rule 2 does so over the period 1985-2007. Rule 2 also dominates over the full sample, whereas the NGDP rules in levels do so during the 1955-1985 period. The impact of the shock to output (and inflation) lasts longer than to welfare, for which it is relatively short.

When considering the technology shock, the on-impact on output is highest under rule 6 whatever the period. Concerning the impact on welfare, rule 3 leads to the strongest impact over the GFC/ZLB period, but several other rules produce results that are nearly as good. The GM period is also characterized by a high value from rule 3 , but some other rules perform nearly 
as well. Before 1985 and over the full sample period, the results are somewhat mixed. As with the monetary policy shock, this impact on output lasts longer than on welfare.

The short-run impact of the government expenditure shock on output does not vary substantially across rules or periods, at least between the GFC/ZLB and the GM periods. Its value is greater, however, over the 19551985 period and over the full sample period. The on-impact on welfare during the 2007-2015 period varies little whatever the rule, whereas rule 2 , followed closely by rules 7 and 8, has the strongest impact over the 1985-2007 period.

Note that if we compare the GM period to the GFC/ZLB period, the government expenditure shock has an impact on output and welfare that lasts significantly longer during the former period than during the latter, whatever the rule used. 

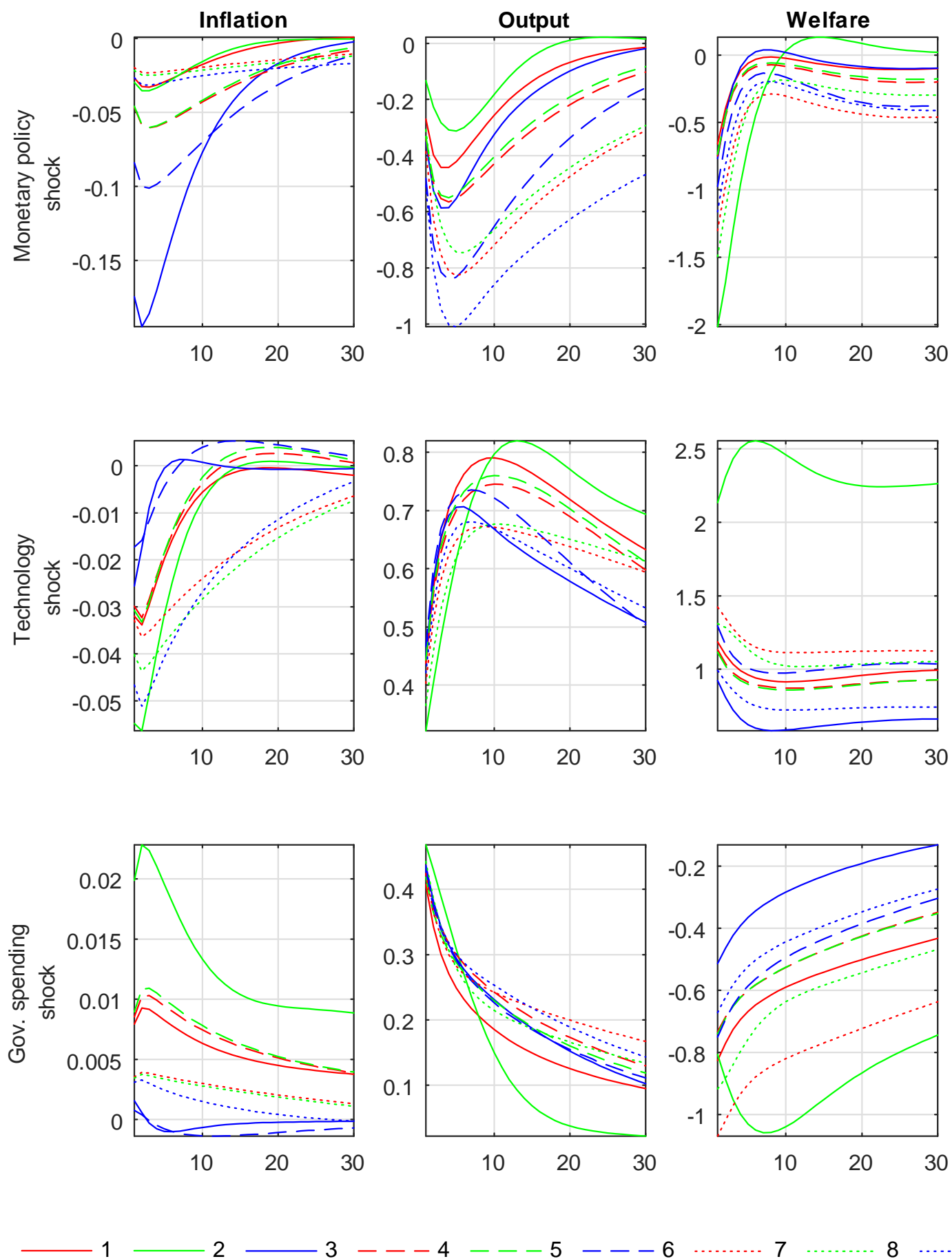

1 2 $3---4---5---6$ 7 8 9

Figure 8: Response of inflation, output and welfare to a $1 \%$ deviation shock between 1955 and 2015 . 

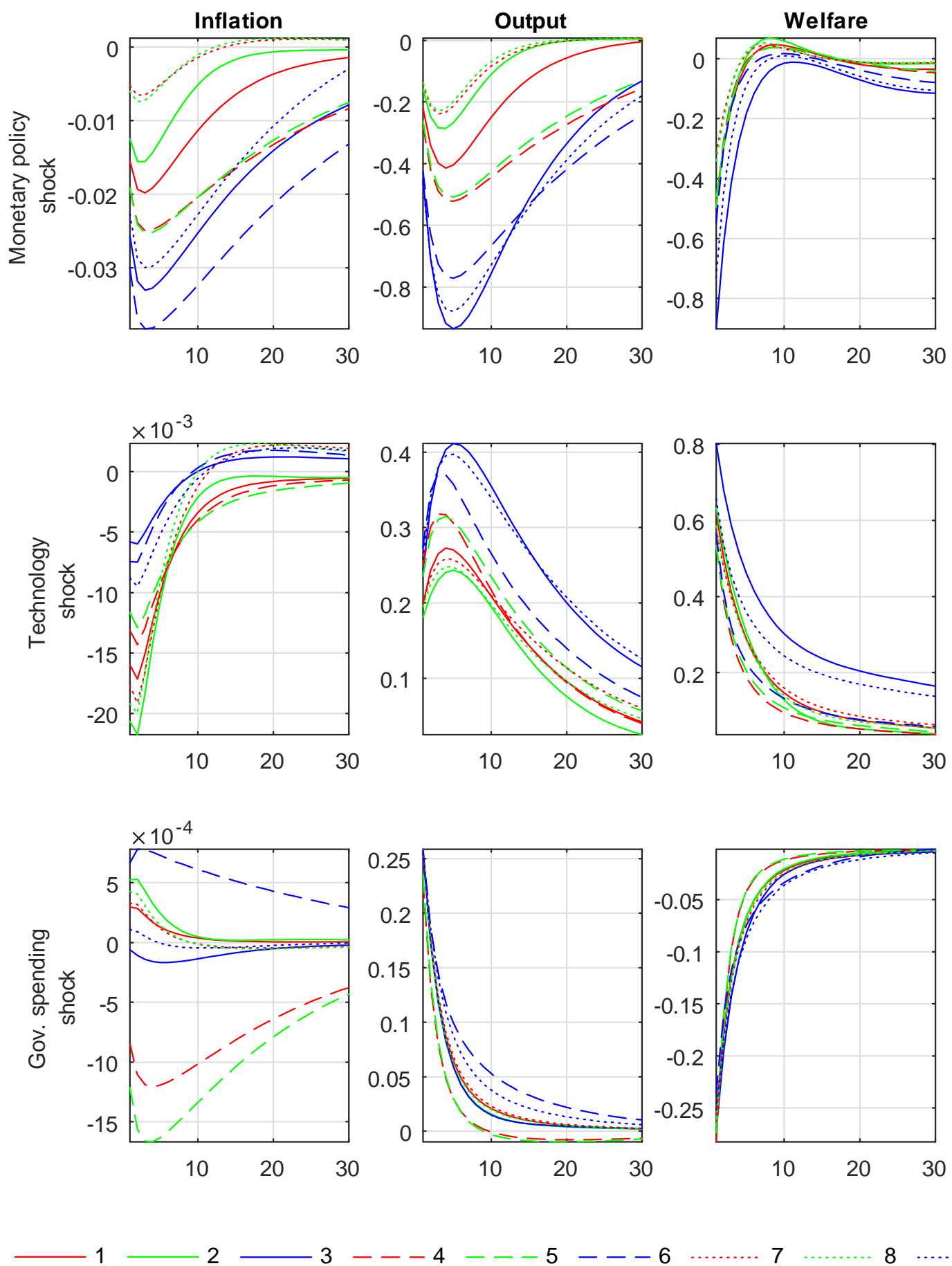

2

$3---4--5--6$

7

8

Figure 9: Response of inflation, output and welfare to a $1 \%$ deviation shock between 2007 and 2015 . 

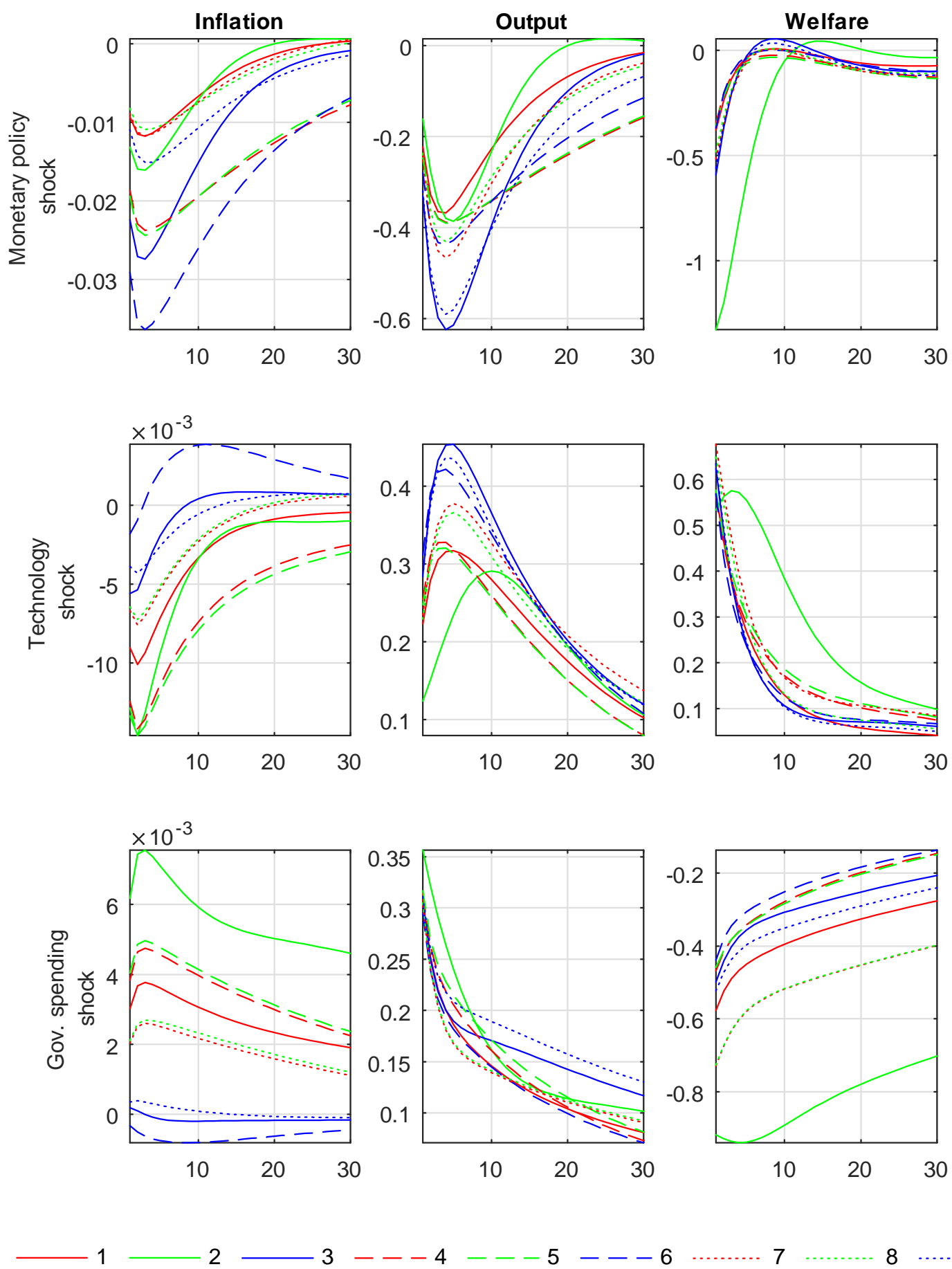

$3---4---5---6$

7

8

Figure 10: Response of inflation, output and welfare to a $1 \%$ deviation shock between 1985 and 2007. 

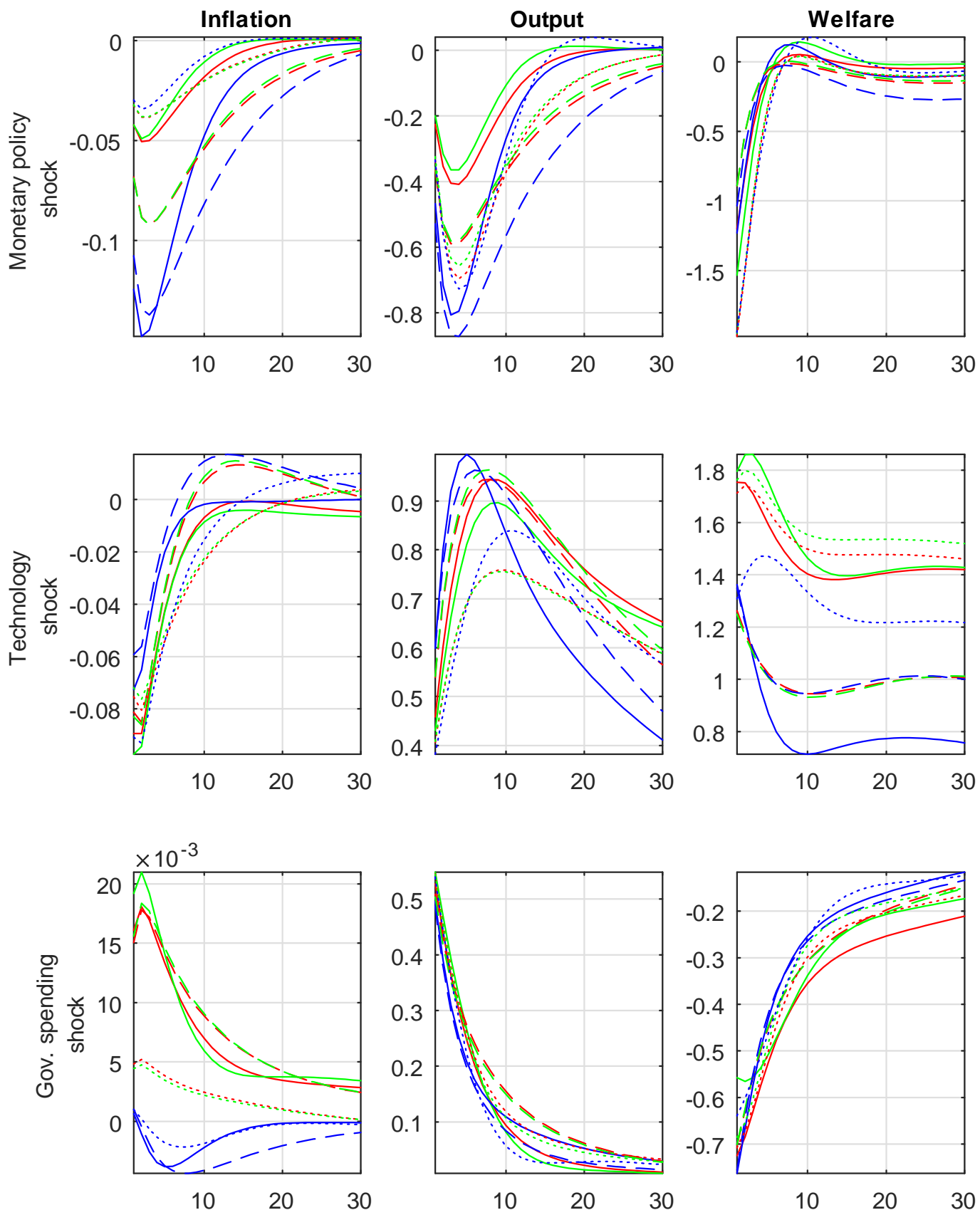

$-1-3---4---5---6$

7

Figure 11: Response of inflation, output and welfare to a 1\% deviation shock between 1955 and 1985 . 


\section{B Variance decompositions}

Figs. 12 to 15 present variance decompositions of the same variables and the same shocks as in the IRFs analysis (Section A). All of the variance decompositions and shocks are included in the Online Appendix.

A comparison between the GFC/ZLB and the GM periods is interesting. In the short and the long run, inflation is explained almost completely by the mark-up shock (Online Appendix). Output variance is impacted by the three shocks we focus on but also by the risk premium shock. The impact of each shock depends on the monetary rule. The impact of the monetary shock is generally greater during the period 2007-2015 than between 1985 and 2007 . It is significant for both periods but more so during the GFC/ZLB than the GM period. Specifically, during the former period, and under rules 3, 6 and 9 , the monetary policy shock explains some $50 \%$ of the output variance in the short run and $70 \%$ in the long run, whereas it is significantly lower under the other rules. But, in both periods, the technology and the government expenditure shocks (as well as the risk premium shock) have also their role to play, especially in the short run. Note further that whatever the shock, it is always rules 3,6 and 9 that lead to the highest variance decomposition for output during the GFC/ZLB period. This result also holds during the GM except for the government expenditure shock where rule 2 (Taylor rule) dominates. Furthermore, note that the government expenditure shock has a relatively lower impact during the GFC/ZLB period than during the GM period.

In both periods, the impact of the monetary and technology shocks on welfare (short and long run) is significant, especially when rules 3,6 and 9 are used (it is rather small with the other rules). The risk premium also has a relatively strong impact, notably during the GFC/ZLB period, when it appears to dominate the others.

The government spending shock has a significant impact on welfare during the GM but a smaller one during the GFC/ZLB period.

For the other periods, the technology shock explains a great deal of the welfare variance, if not always in the short run, at least in the long run. Output in the long run is also substantially impacted by the technology shock in the 1955-1985 period and over the full sample period. Of course, these impacts are more or less significant depending on the monetary rule used. Generally, rules 3, 6 and 9 (rules including the natural interest rate in the monetary rules) explain the highest variance of output and welfare, whatever the shock, except for the government expenditure shock, where this pattern is not always respected. 

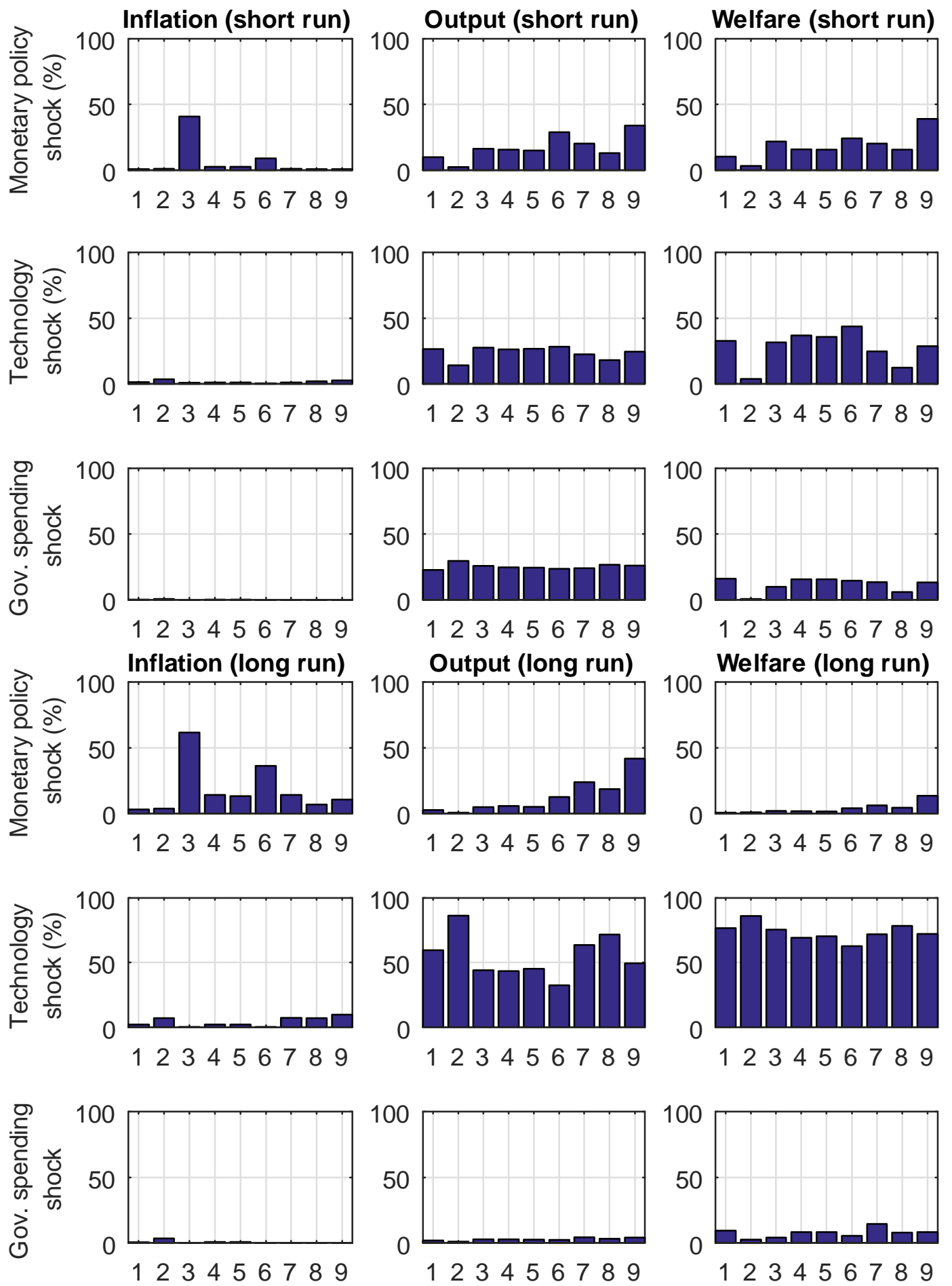

Figure 12: Short- and long-run variance decompositions of inflation, output and welfare between 1955 and 2015 . 

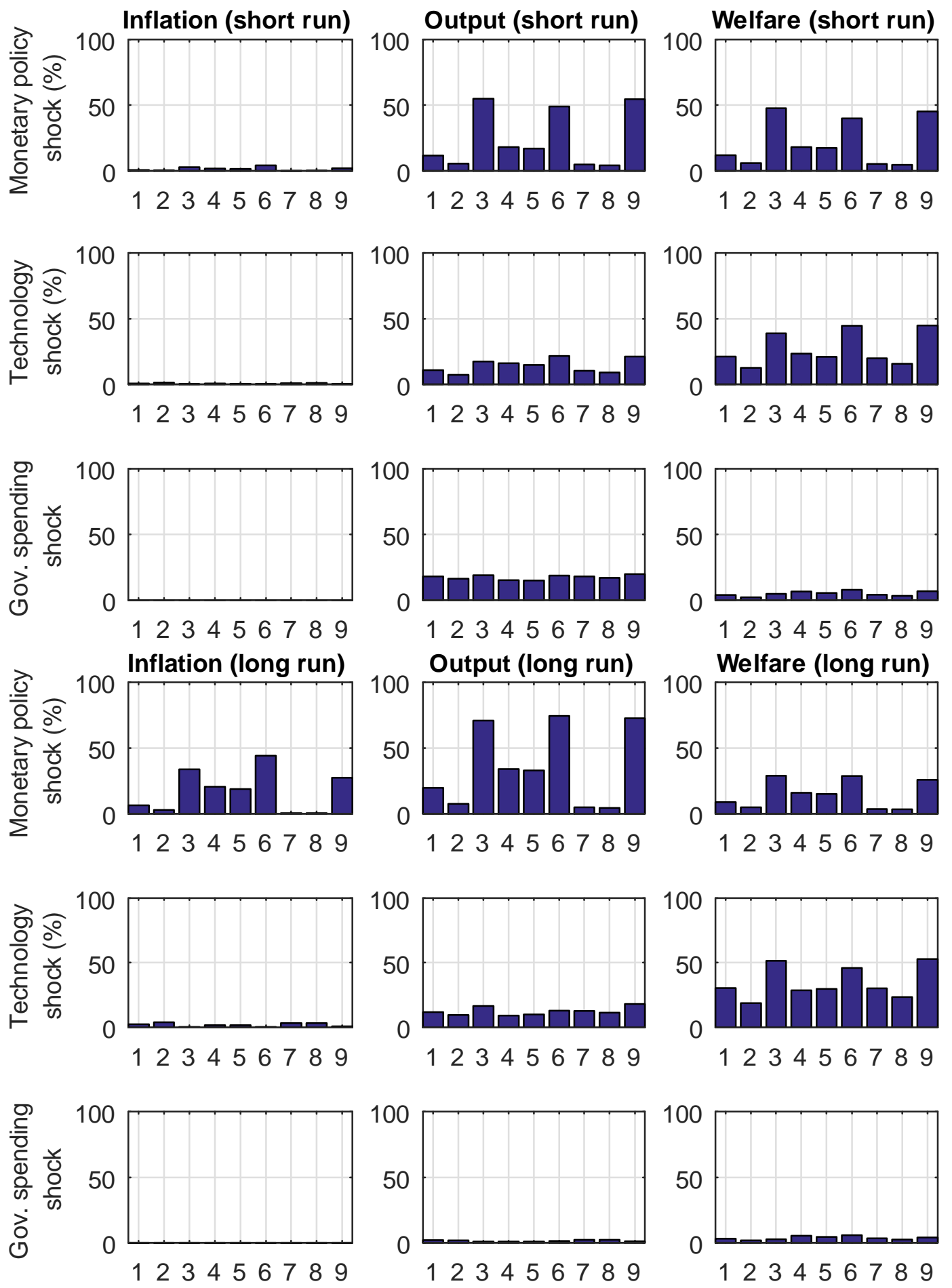

Figure 13: Short- and long-run variance decompositions of inflation, output and welfare between 2007 and 2015 . 

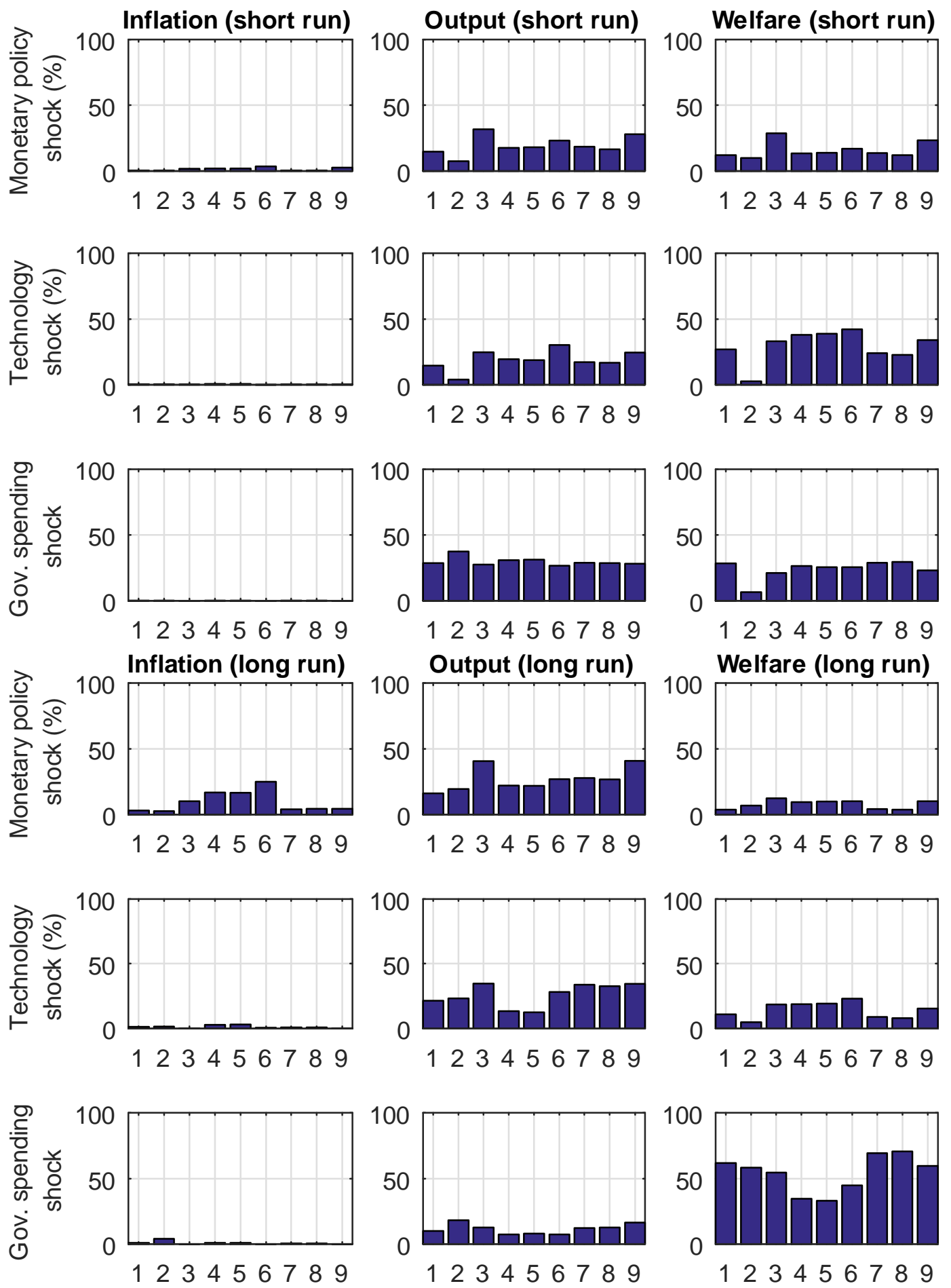

Figure 14: Short- and long-run variance decompositions of inflation, output and welfare between 1985 and 2007. 

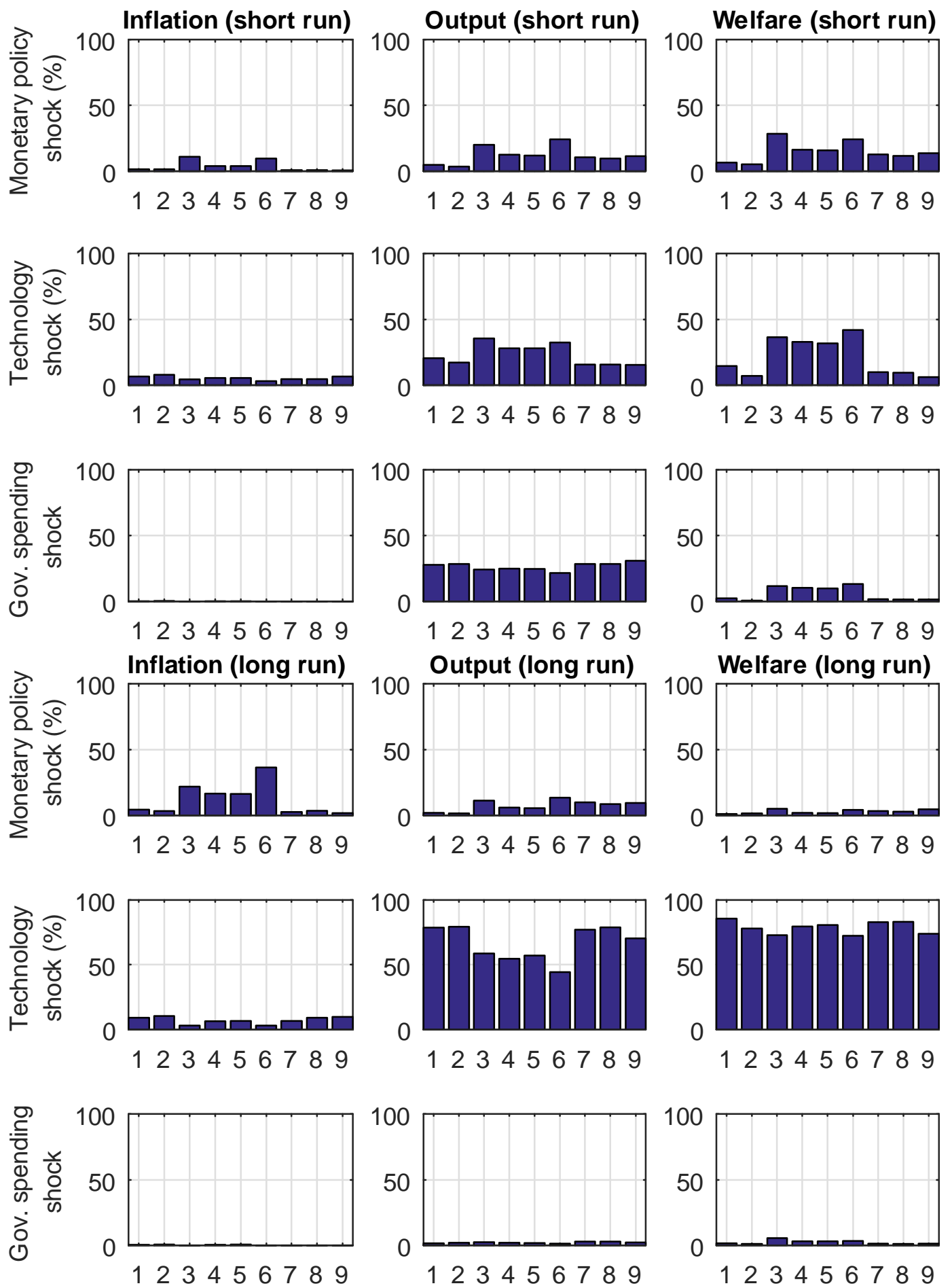

Figure 15: Short- and long-run variance decompositions of inflation, output and welfare between 1955 and 1985 . 


\section{References}

Adolfson, M., Laséen, S., Lindé, J., Svensson, L. E., 2011. Optimal monetary policy in an operational medium-sized DSGE model. Journal of Money, Credit and Banking 43 (7), 1287-1331.

Adolfson, M., Laséen, S., Lindé, J., Svensson, L. E., 2014. Monetary policy trade-offs in an estimated open-economy DSGE model. Journal of Economic Dynamics and Control 42, 33-49.

An, S., Schorfheide, F., 2007. Bayesian analysis of DSGE models. Econometric Reviews 26 (2-4), 113-172.

Belongia, M. T., Ireland, P. N., 2015. A "working" solution to the question of nominal GDP targeting. Macroeconomic Dynamics 19 (03), 508-534.

Benchimol, J., Fourçans, A., 2017. Money and monetary policy in the Eurozone: an empirical analysis during crises. Forthcoming in Macroeconomic Dynamics.

Bernanke, B., Mishkin, F., 1997. Inflation targeting: a new framework for monetary policy? Journal of Economic Perspectives 11 (2), 97-116.

Clarida, J. B., 2010. The mean of the new normal is an observation rarely realized: focus also on the tails. Global perspectives, PIMCO.

Cúrdia, V., Woodford, M., 2011. The central-bank balance sheet as an instrument of monetary policy. Journal of Monetary Economics 58 (1), 54-79.

Del Negro, M., Schorfheide, F., Smets, F., Wouters, R., 2007. On the fit of New Keynesian models. Journal of Business \& Economic Statistics 25, $123-143$.

Fair, R. C., Howrey, E. P., 1996. Evaluating alternative monetary policy rules. Journal of Monetary Economics 38 (2), 173-193.

Fernández-Villaverde, J., Rubio-Ramírez, J. F., 2004. Comparing dynamic equilibrium models to data: a Bayesian approach. Journal of Econometrics 123 (1), 153-187.

Frankel, J., 2014. Nominal GDP targeting for middle-income countries. Central Bank Review 14 (3), 1-14.

Frankel, J., Chinn, M., 1995. The stabilizing properties of a nominal GNP rule. Journal of Money, Credit and Banking 27 (2), 318-334. 
Friedman, M., 1971. A monetary theory of nominal income. Journal of Political Economy 79 (2), 323-337.

Friedman, M., 1982. Monetary policy: theory and practice. Journal of Money, Credit and Banking 14 (1), 98Ü118.

Galí, J., 2015. Monetary policy, inflation and the business cycle: an introduction to the New Keynesian framework. Princeton, NJ: Princeton University Press.

Garín, J., Lester, R., Sims, E., 2016. On the desirability of nominal GDP targeting. Journal of Economic Dynamics and Control 69, 21-44.

Gorton, G. B., 2009. Information, liquidity, and the (ongoing) panic of 2007. American Economic Review 99 (2), 567-72.

Hall, R., Mankiw, N., 1994. Nominal income targeting. Working Papers 4439, National Bureau of Economic Research.

Hendrickson, J., 2012. An overhaul of Federal Reserve doctrine: nominal income and the Great Moderation. Journal of Macroeconomics 34 (2), $304-317$.

Justiniano, A., Preston, B., 2010. Can structural small open-economy models account for the influence of foreign disturbances? Journal of International Economics 81 (1), 61-74.

Koop, G., 2003. Bayesian Econometrics. New York, NY: John Wiley \& Sons.

Kydland, F. E., Prescott, E. C., 1977. Rules rather than discretion: the inconsistency of optimal plans. Journal of Political Economy 85 (3), 47391.

McCallum, B. T., 1973. Friedman's missing equation: another approach. Manchester School 41 (3), 311-328.

McCallum, B. T., 1987. The case for rules in the conduct of monetary policy: a concrete example. Review of World Economics 123 (3), 415-429.

McCallum, B. T., 2015. Nominal GDP targeting: Policy rule or discretionary splurge? Journal of Financial Stability 17, 76-80.

McCallum, B. T., Nelson, E., 1999. Nominal income targeting in an openeconomy optimizing model. Journal of Monetary Economics 43 (3), 553578. 
Meade, J. E., 1978. The meaning of internal balance. Economic Journal 88 (351), 423-435.

Meltzer, A. H., 2012. Federal Reserve policy in the Great Recession. Cato Journal 32 (2), 255-263.

Nikolsko-Rzhevskyy, A., Papell, D., 2012. Taylor rules and the Great Inflation. Journal of Macroeconomics 34 (4), 903-918.

Nikolsko-Rzhevskyy, A., Papell, D. H., Prodan, R., 2014. Deviations from rules-based policy and their effects. Journal of Economic Dynamics and Control 49, 4-17.

Rudebusch, G., 2002a. Assessing nominal income rules for monetary policy with model and data uncertainty. Economic Journal 112 (479), 402-432.

Rudebusch, G. D., 2002b. Term structure evidence on interest rate smoothing and monetary policy inertia. Journal of Monetary Economics 49 (6), 11611187.

Smets, F., Wouters, R., 2003. An estimated dynamic stochastic general equilibrium model of the Euro area. Journal of the European Economic Association 1 (5), 1123-1175.

Smets, F., Wouters, R., 2007. Shocks and frictions in US business cycles: a Bayesian DSGE approach. American Economic Review 97 (3), 586-606.

Sumner, S., 2014. Nominal GDP targeting: a simple rule to improve Fed performance. Cato Journal 34 (2), 315-337.

Sumner, S., 2015. Nominal GDP futures targeting. Journal of Financial Stability $17,65-75$.

Svensson, L., 1999. Inflation targeting as a monetary policy rule. Journal of Monetary Economics 43 (3), 607-654.

Svensson, L. E., Williams, N., 2009. Optimal monetary policy under uncertainty in DSGE models: a Markov jump-linear-quadratic approach. In: Central Banking, Analysis, and Economic Policies Book Series. Vol. 13. Central Bank of Chile, pp. 077-114.

Taylor, J. B., 1979. Staggered wage setting in a macro model. American Economic Review 69 (2), 108-13. 
Taylor, J. B., 1986. An appeal for rationality in the policy activism debate. In: R.W. Hafer, ed. The monetary versus fiscal policy debate: lessons from two decades. Littlefield, NJ: Rowman and Allenheld, pp. 151-163.

Taylor, J. B., 1987. Externalities associated with nominal price and wage rigidities. In: W.A. Barnett and K.J. Singleton, eds. New approaches to monetary economics. Cambridge, UK: Cambridge University Press, pp. $350-367$.

Taylor, J. B., 1993. Discretion versus policy rules in practice. CarnegieRochester Conference Series on Public Policy 39 (1), 195-214.

Taylor, J. B., 1999. A historical analysis of monetary policy rules. In: NBER Chapters. National Bureau of Economic Research, Inc, pp. 319-348.

Taylor, J. B., 2012. Monetary policy rules work and discretion doesn't: a tale of two eras. Journal of Money, Credit and Banking 44 (6), 1017-1032.

Taylor, J. B., 2013. MacroMania on nominal GDP targeting and the Taylor rule. Blog post, EconomicsOne.com.

Taylor, J. B., Wieland, V., 2012. Surprising comparative properties of monetary models: results from a new model database. The Review of Economics and Statistics 94 (3), 800-816.

Woodford, M., 2012. Methods of policy accommodation at the interest-rate lower bound. Proceedings - Economic Policy Symposium - Jackson Hole, $185-288$. 


\section{PARIS}

ESSEC Business School

3, avenue Bernard-Hirsch

CS 50105 Cergy

95021 Cergy-Pontoise Cedex

France

Têl. +33 (0)134433000

www.essec.edu
ESSEC Executive Education

CNIT BP 230

92053 Paris-La Défense

France

Têl. +33 (0)146924900

www.executive-education.essec.ff
ESSEC Asia-Pacific

5 Nepal Park

Singapore 139408

Têl. +65 68849780

www.essec.edu/asia

\section{SINGAPOUR}

Contact :

Centre de Recherche

+33 (0)134433091

research.center@essec.fr

ISSN 1291-9616 